Journal of the Scientific Agricultural Society of Finland Vol. 51: 327-379, 1979

Maataloustieteellinen Aikakauskirja

\title{
SEED-BORNE FUNGI ON CRUCIFEROUS \\ CULTIVATED PLANTS IN FINLAND AND THEIR IMPORTANCE IN SEEDLING RAISING
}

Selostus: Ristikukkaisten viljelykasvien siemenlevintäiset sienet Suomessa ja niiden merkitys taimikasvatuksessa

R ISTO TAH V O E N

Department of Plant Pathology, University of Helsinki Viikki, SF-00710 Helsinki 71, Finland

TO BE PRESENTED, WITH THE PERMISSION OF THE Faculty of Agriculture and Forestry of the UNIVERSITY OF HELSINKI, FOR PUBLIC CRITICISM AT VIIKKi IN AUditorium B 3 ON October 27, 1979 AT 10 o'CLOCK 



\section{Preface}

This study has been carried out at the Deparment of Plant Pathology of the University of Helsinki. I would like to extend my sincere thanks to the Head of the Deparment, Prof. Eeva TAPIO, Dr. Agr. and For., for the support she has given me during the course of this study and for the valuable advice offered me during the preparation of the manuscript.

The study into the seed-borne fungi of Cruciferous plants was started at the instigation of, and under the guidance of, Mrs. KaIнo MäKEL for her advice in the planning of the study and especially for the inspiring example of plant pathology research.

I would like to extend my gratitude to the personal of the Department of Plant Pathology, especially to Mr. Pentri Heinänen, Mr. Tauno Koivunen, Miss. Lahja Pesonen and to the trainers at the Department for their invaluable assistance in carrying out the practical side of the study.

The State Seed Testing Station, the Institute of Horticulture at Piikkiö, the Institute of Horticulture of the University of Helsinki, a number of seed firms and the Society of Agronomists have provided research material and financial support. Mr. John Derome M. Sc. has translated the manuscript into English.

Finally I would like to thank the Scientific Agricultural Society of Finland for giving permission for this study to be published in their series.

Helsinki, March 1979

Risto Tahvonen 



\section{CONTENTS}

Abstract

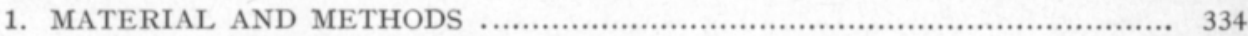

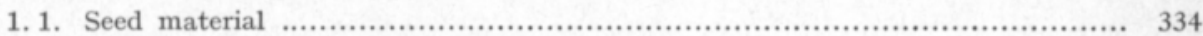

1. 2. Fungal determinations carried out on the seeds .................................. 337

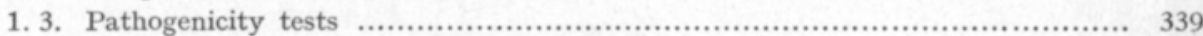

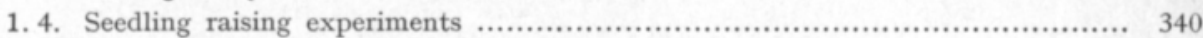

1. 4. 1. Effect of fungi on seedling emergence and growth .................... 340

1. 4. 2. Importance of growing substrate ........................................ 341

1. 4. 3. Effect of temperature on damping-off and growth ..................... 341

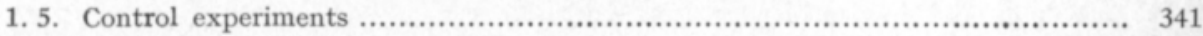

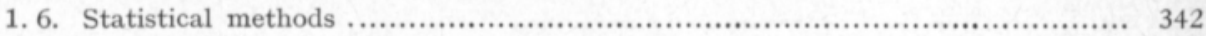

2. SEED-BORNE FUNGI OF CRUCIFEROUS CULTIVATED PLANTS $\ldots \ldots \ldots \ldots \ldots \ldots . . . \ldots 42$

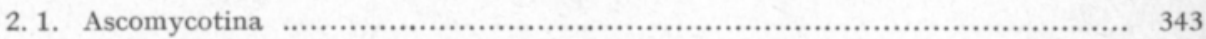

Pleospora herbarum ...................................................................... 343

Whetzelinia sclerotionum ............................................................... 343

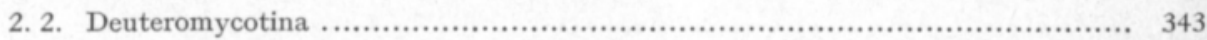

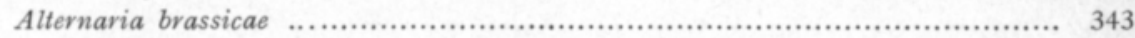

Alternaria brassicicola .................................................................... 344

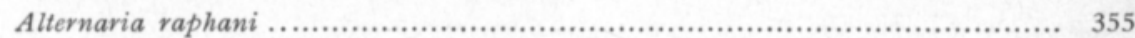

Botrytis cinerea ........................................................................ 355

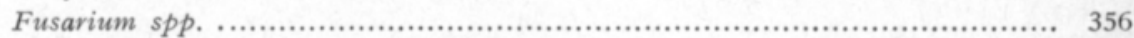

Plenodomus lingam ...................................................................... 356

Rhizoctonia solani ...................................................................... 357

Ulocladium concortiale ................................................................... 358

2. 3. Other fungi on cruciferous seeds ................................................... 358

3. IMPORTANCE OF SEED-BORNE FUNGI OF CRUCIFERS IN SEEDLING RAISING

3. 1. Effect of seed-borne fungi on seedling emergence and seedling growth ......... 362

3.1.1. Damping-off .................................................................... 362

3.1.2. Seedling growth ............................................................. 363

3. 1. 3. Importance of contamination in peat substrate ......................... 364

3. 2. Effect of different growth substrates on Alternaria brassicicola and Plenodomus

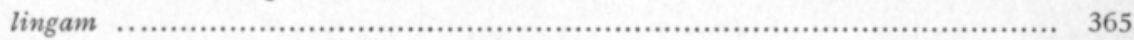

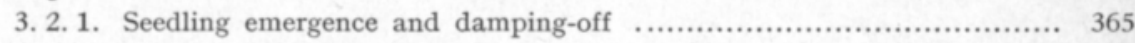

3. 2. 2. Spreading of the fungi ................................................... 366

3. 3. Effect of temperature on Alternaria brassicicola and Plenodomus lingam in seedling raising ............................................................................. 368

3. 3. 1. Alternaria brassicicola ...................................................... 368

3. 3. 2. Plenodomus lingam ....................................................... 368

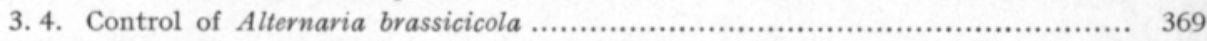

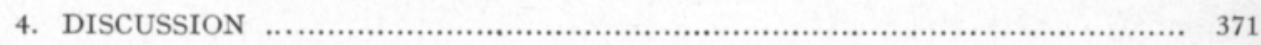

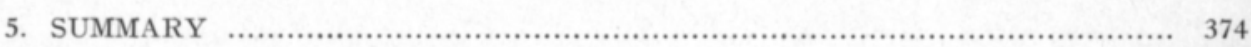

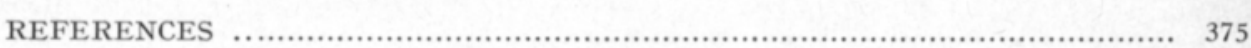

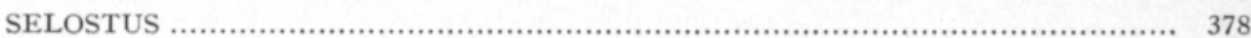





\section{TAHVonen, R. 1979. Seed-borne fungi on cruciferous cultivated plants in Finland and their importance in seedling raising} J. Scient. Agric. Soc. Finl. 51: 327-379.

Abstract. The seed-borne fungi of cabbage, swede, turnip, rape, turnip rape, radish and black radish and their importance in seedling raising have been examined in this study. The seed lots used in the study were on sale at seed merchants in Finland during the period $1968-1976$.

Alternaria brassicicola (Schw.) Wiltshire was the most common pathogen, being more common on cabbage than on any of the other plant species. $91 \%$ of the white cabbage and red cabbage seed lots were infected. The mean $A$. brassicicola contents of the infected seed lots were $29.5 \%$ and $30.6 \%$. Plenodomus lingam (Tode ex Fr.) Höhnel occurred in $10 \%$ of the white cabbage and $27 \%$ of the red cabbage seed lots, the fungus content varying from $0.5 \%$ to $14 \%$. The fungus was also found on cauliflower, swede and radish. Alternaria brassicae (Berk.) Sacc. was found in $4 \%$ of the cabbage and in $31 \%$ of the rape seed lots at fungus contents of $0.5-6.5 \%$. Alternaria raphani Groves \& Skolko was found in $30 \%$ of the radish and black radish seed lots at fungus contents of $0.5-8 \%$. The following fungi were also found on the seeds of Cruciferous plants: Pleospora herbarum (Pers.) Rabenh., Whetzelinia sclerotiorum (Lib) Korf \& Dumont, Botrytis cinerea Pers., Ulocladium concortiale (Thum.) Simmons, Fusarium spp. and Rhizoctonia solani Kühn as well as 18 fungus genera and species either saprophytic or pathogenic to other plants.

When the Alternaria brassicicola content of the seeds was $20 \%$ it caused $10 \%$ damping-off damage on the sand substrate. A similar level of damge occurred on the peat substrate when the fungus content reached $70 \%$. In addition to causing dampingoff and damaging the seedlings, the fungus also slowed-down seedling growth without apparently damaging them. When the seedlings were grown at a lower temperature the amount of damage caused by $A$. brassicicola was much less than that which occurred when a higher temperature was used. Plenodomus lingam caused as much damping-off as there were seeds infected with the fungi. Other seed-borne fungi had no importance in seedling raising.

Sphagnum fuscum peat, which is used in Finland as a growth substrate, reduced the amount of damping-off caused by seed-borne fungi in comparison to disinfected substrates and prevented the spread of $A$. brassicicola and $P$. lingam from diseased to healthy seeds. Dressing the seeds with thiram proved to be very effective against A. brassicicola. 


\section{Introduction}

The cultivation of cruciferous plants plays a significant role in both agriculture and market gardening in Finland. The area under rape and turnip rape has increased from 6600 ha to 31700 ha during the 1970's. The cultivation of various types of cabbage has also increased during the last few years as a result of agricultural specialisation from about 1000 ha to 1350 ha. Other cruciferous species, such as swede, turnip and radish, have also attained a strong position in cultivation.

Cabbage cultivation in Finland is mainly based on seedling raising. As seedling raising was earlier carried out on different types of mull mixtures, soil-borne damping-off fungi were a serious problem (Linnasalmi 1952). Nowadays, however, fresh peat, which is generally considered to be free from plant pathogens, is usually used as the substrate. The time required to raise seedlings has been reduced from about six weeks to $3-4$ weeks by raising the temperature at which the seedlings are grown. The most recent cultivation techniques have greatly decreased the risk of soil-borne damping-off and the only remaining problem is seed-borne fungi, since the health of seeds of garden plants is not checked very stringently in Finland during seed inspection.

The most important seed-borne fungi of cruciferous plants are Plenodomus lingam (Tode ex Fr.) Höhnel, Alternaria brassicae (Berk.) Sacc. and A.brassicicola (Schw.) Wiltshire. P. lingam causes damping-off, especially under moist conditions and dry rot during the growing season (HENDERSON 1918). Even with a very low degree of infection in a seed lot (about $0.5 \%$ ), under conditions favourable to this fungus there is a danger that the disease will break out (Allen and Sмith 1961). Alternaria $s p p$. cause the most serious damage in seed crops by attacking the siliqua, thus reducing the yield and quality of the seed crop. Severe infection in the seeds causes damping-off and deformation of the seedlings (NIELSEN 1933). In addition to these fungi, radish is also susceptible to the seed-borne fungus, A. raphani Groves \& Skolko (NEERGAARD 1945). Many of the other fungus diseases to which cruciferous plants are susceptible can spread via the seeds, but they have no practical importance as far as seed-borne infection is concerned.

The aim of this study is to determine the seed-borne fungi of cruciferous plants in Finland and their importance in the light of present-day cultivation techniques. The study has been carried out at the Department of Plant Pathology, the University of Helsinki, during the years 1971-77.

\section{Material and methods}

\section{1. Seed material}

The seeds of white cabbage, cauliflower and red cabbage, which were examined in the study, were on sale in Finland during 1968-1976. The other species of cabbage were from 1972-1976. The seeds of swede, turnip, marrow 
kale, radish, black radish, rape and turnip rape had been on sale during the period 1974-1976. The majority of the seeds were obtained from samples received by the State Seed Testing Station. The rest of the seed samples were obtained from the Institute of Horticulture at the University of Helsinki, the Institute of Horticulture at Piikkiö and various seed-handling firms. The abbreviations used to denote the origin of the seeds are as follows: $\mathrm{AH}=$ A. Hansens Amagerfrö (Denmark), FM = Ferry-Morse Seed Company (USA), $\mathrm{OE}=\mathrm{J}$. E. Ohlsen's Enke (Denmark), $\mathrm{Hg}=$ Hammenhögs Frö (Sweden), $\mathrm{LD}=\mathrm{A} / \mathrm{S} \mathrm{L}$. Daehnfeldt (Denmark), NK = Northrup King \& Co (USA), $\mathrm{WW}=\mathrm{W}$. Weibull $\mathrm{Ab}$ (Sweden) and $\mathrm{ZW}=\mathrm{N} . \mathrm{V}$. Rijk Zwaan (Holland). It was not always possible to obtain reliable information about the origin of the seeds owing to the lack of detailed information on the seed packets. Similarly, the actual year when the seeds were grown could not be determined for all the seed samples. For this reason, the seeds were not grouped according to the year when they were grown. A total of 59562 seeds from 272 seed lots were studied using the blotter method. Seed lots infected to varying degrees were selected for further study. The seeds were germinated on agar and allowed to develop into seedlings. The seed lots selected for further study are listed in the description of the test in question.

The number of seed samples of cabbage species examined in the study was equivalent to one half to one third of the number of such samples sent each year to the State Seed Testing Station and for other species from one third to one seventh (YLLö 1972). It was not always possible to examine the reguired lots of oil plants and marrow kale because in many cases the seeds had been dressed by the seed producer. An attempt was made to select those varieties which are most commonly cultivated and preferred in Finland. As far as possible the different lots of the same variety were selected from different growing years and from different selling years. Although it was possible to examine only few lots of some plant species and varieties, the results are at any rate suggestive. The following plant species and varieties were included in the sudy:

Plant species

White cabbage

(Brassica oleracea $\mathrm{v}$. capitata alba)
Variety

Amager low

Amager halfhigh

Amager stonehead No 80

Ditmarsk

Faales Blåtopp

Futura $\mathrm{F}_{1}$

Jågeru

Kuusiku varajane

Copenhagen market

Länsipohja

Pondus

Respla

Ruhm v. Enkhuizen
Number of Origin lots

$\begin{array}{rl}1 & \text { OE } \\ 2 & \mathrm{Hg} \\ 3 & \\ 9 & \text { OE } \\ 10 & \\ 6 & \text { OE } \\ 1 & \text { Estonia } \\ 1 & \text { Estonia } \\ 12 & \text { AH } \\ 8 & \\ 1 & \text { WW } \\ 1 & \text { Norway } \\ 11 & \text { OE }\end{array}$


Cauliflower

(Brassica oleracea

v. botrytis)

Red cabbage

(Brassica oleracea

v. capitata rubra)

Kohl-rabi

(Brassico oleracea

v. gongyloides)

Kale

(Brassica oleracea v. acephala)

Broccoli

(Brassica oleracea

v. asparagoides)

Marrow kale

(Brassica oleracea v. acephala $\mathbf{x}$. gongyloides)

Brussels sprouts

(Brassica oleracea

v. gemmifera)

Savoy cabbage

(Brassica oleracea

v. subauda)

Swede

(Brassica napus

v. napobrassica)
Bravo

Brio Enkoma P 68

1

$\mathrm{OE}$

Cumulus

Eminent Hunderup

LD

Erfurter 291

$\mathrm{AH}$

Erfurter 986

$\mathrm{AH}$

Flora Blanca

ZW

Hama

$\mathrm{Hg}$

Idol

OE

Igloo

$\mathrm{OE}$

Urania

WW

total 51

Amager 304

Baby

Haco

9

$\mathrm{AH}$

Langendiger Sommer

SG

WW

total 21

Prager 2

White Ulmer 3

total 5

Green half high 3

\begin{tabular}{llll} 
Green leaf No 252 P 60 & & 1 & \\
\hline & total & 4 & \\
Crusader & & 1 & $\mathrm{NK}$ \\
Greenia & & 3 & $\mathrm{Hg}$ \\
Green Mountain & 1 & WW \\
Waltham No 29 & 2 & FM \\
\hline & total & 7 & \\
\hline & total & 8 &
\end{tabular}

Early dwarf 2

Jade 4

Eisenkopf 1

Ulmer 3

Wertus 1

\begin{tabular}{|c|c|}
\hline Bankholm & 2 \\
\hline Gullâker & 3 \\
\hline Mustiala & 4 \\
\hline Pandur & 5 \\
\hline Yellow Swedish & 5 \\
\hline Tammisto & 4 \\
\hline Ostgöta & 2 \\
\hline
\end{tabular}


Turnip

(Brassica campestris

v. rapa)

Rape

(Brassica napus

v. oleifers)

Turnip rape

(Brassica rapa

v. oleifera)

Radish

(Raphanus sativus

v. radicula)

Black radish

(Raphanus sativus subsp. niger
Barenza

Gold ball

Petrawsky

Teutoburger

Yellow Tankard

Östersundom

\begin{tabular}{lr} 
Östersundom & 3 \\
\hline total & 18
\end{tabular}

Alku

Early Giant

Escofar

Hankkijan Lauri

Jo 038

Oro

2

2

4

4

3

3

total 13

Bele

Hankkijan Simeoni

Gold

Rapido I

Torpe

\section{2}

2

1

1

1

6

13

total 13

Cherry Belle $\quad 1$

Copenhagen market 4

Non Plus Ultra 3

Pernot 2

Halv long $\quad 2$

Saldo $\quad 1$

Saxa 3

total 17

Rosa-red Chinese 1

Black round 1

Neckarruhm 1

total 3

\section{2. Fungal determinations carried out on the seeds}

Between 200 and 400 seeds were studied in each lot, depending on the nature and degree of the fungal infection. A smaller number were examined if the first 200 seeds in the seed sample were either all healthy or contained only saprophytic fungi. If important seed-borne fungi were found then, in addition to the 200 seeds, a further sample was taken. In this case the size of the studied seed sample was the same as is recommended for the health inspection of a number of different species of seed (Anon. 1966). The taking of 1000 seed samples, which is recommended for the inspection of the seeds of cruciferous plants, was considered to be unnecessarily large in this study.

The seeds were germinated in eight batches of 25 seeds each in a Jacobsen germinator. The seeds were placed on moist filter paper and covered by a glass hood with a ventilation hole in the center (Fig. 7). 
In 1971 and 1972 , the seeds were germinated in the laboratory where the air temperature varied between $20-25^{\circ} \mathrm{C}$. In following years germination was carried out in a room fitted with cooling and heating equipment where the day temperature was maintained at $20^{\circ} \mathrm{C}$ and the night temperature at $18^{\circ} \mathrm{C}$. During the first two years of the study, the seeds were germinated under normal lighting conditions in which the day-length was the same as that normally occurring during the summer in Helsinki. The following year the batch was illuminated with low-pressure mercury vapour lamps for 12 hours each 24 hour period. The mean illumination intensity was $1850 \mathrm{lux}$, measured at the same height as the seeds. The examination method used was the blotter method described de TEMPE (1963), in which germination is carried out in the light so that the saprophytic and weakly pathogenic fungi do not damage the growing seedlings, as is likely to happen when germination is carried out in the dark. Providing illumination during 12 hour periods was considered to be important for the abundant production of conidia by the fungi, which greatly simplifies identification (ANON. 1966).

The seeds were examined 6 and 10 days after seeding. The number of germinated seeds was counted during the first examination. The fungi were identified by examining them under a stereomicroscope with magnification of 7-88. Penicillium spp. and Rhizopus nigrigans were noted only during the first inspection. A number of the seed-borne fungi which affect the seeds of cruciferous plants could be identified directly under the stereo-microscope. The number of seedlings which died after germination was also noted during the inspection. Examination with a stereo-microscope was supplemented by the use of a light microscope. Slides were prepared using lactic acid and lactophenol solution $\left(\mathrm{H}_{2} \mathrm{O} 20 \mathrm{~g}\right.$, phenol $20 \mathrm{~g}$, lactic acid $20 \mathrm{~g}$, glycerol $40 \mathrm{~g}$ and trypan blue $0.05 \mathrm{~g}$ ) and the fungi subsequently measured and photographed. During the incubation period, only fungi producing mycelia, and fungi to be isolated for further study, were transferred to potato-dextrose agar (PDA, Difco). Whenever necessary, growth of the seedlings was continued after the second inspection by transferring them onto blotting paper in a petri dish. The classification of Ainsworth et al. (1973 a, $1973 \mathrm{~b})$ was used.

In addition to the blotter method, some of the diseased seed lots and lots infected with a number of different fungi (10 white cabbage, 3 cauliflower, 1 broccoli and 1 kale lot) were studied using the agar method at temperatures of $20^{\circ}$ and $5^{\circ} \mathrm{C}$ in order to determine the presence of fungi which possibly may not have developed with the blotter method. Two batches of 50 seeds from each seed lot were sown on maize medium (corn meal agar, Difco) in petri dishes $(\varnothing 14 \mathrm{~cm})$ and incubated at both temperatures. The dishes incubated at $20^{\circ} \mathrm{C}$ were examined 6 and 10 days after sowing, and those kept at $5^{\circ} \mathrm{C}$ three times after intervals of two weeks. A low temperature was used so as to allow slowgrowing fungi, which were hidden by fast-growing fungi at high temperatures, to develop. The results obtained with the agar method have been mentioned only in cases where the results differed, as regards species composition, from those obtained with the blotter-method.

In 1975-1977 seeds from seriously diseased lots and those infected by a number of different fungi were sown in petri dishes $(\varnothing=14 \mathrm{~cm})$. Prior to seed- 
ing, $2 \times 50$ seeds were washed for $10 \mathrm{~min}$ in $1 \% \mathrm{NaClO}$ (to sterilise the surface of the seeds) and then washed carefully with distilled water. $2 \times 50$ seeds were left untreated from each lot. The seeds were examined 6 and 10 days after sowing and the petri dishes then kept for $4-6$ weeks at $5^{\circ} \mathrm{C}$ before the third and final inspection. Surface sterilisation was used in an attempt to determine whether any fungi were present under the surface contamination and which fungi, and to what extent, contaminate the surface of the seeds of cruciferous plants. The number of seed lots of different cruciferous plants, examined in this part of the study, were as follows: 7 white chabbage, 1 cauliflower, 4 marrow kale, 3 swede, 3 turnip, 3 rape, 5 turnip rape, 3 radish and 1 black radish.

\subsection{Pathogenicity tests}

The seeds used in the pathogenicity tests were seeds which were as healthy as possible and which had a high germination percentage. Surface sterilisation was carried out in the same way as for the health inspection by the agar method. The seeds were dried overnight between filter papers at room temperature. Surface sterilisation was carried out in order to remove any contaminants from the surface of the seeds which might have affected the results.

The fungi under study were cultivated for 7 days at $20^{\circ} \mathrm{C}$ on PDA medium. The mycelium was then scraped off and suspended in $100 \mathrm{ml}$ of sterile water. A fine suspension was then made by mixing with an Ultra-Turrax homogeniser and the suspension subsequently diluted five times with sterile water. Surface sterilised seeds $(2 \mathrm{~g})$ were then soaked for one minute in the fungal suspension and the seeds dried overnight between filter papers. Two lots of 25 inoculated seeds each were sown in a Jacobsen germinator. Preliminary tests were carried out in order to determine the optimum concentration of the fungal suspension, the correct dilution factor then being calculated. The extent of damage caused to the seedlings was examined 7, 10 and 14 days after seeding. Damage was assessed using a four degree scale in which $0=$ healthy, $1=$ slightly damaged, $2=$ severely damaged and $3=$ dead.

The cruciferous species and varieties examined in the pathogenicity tests are shown in Figures 1,2 and 3. The following fungal isolates were used:

Test n:o

Fig. 1

Alternaria brassicicola

A. raphani

Botrytis cinerea

Fusarium oxysporum

Plenodomus lingam

Fig. 2

\begin{tabular}{|c|c|}
\hline A. brassicicola & $' T H '$ \\
\hline 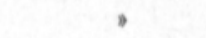 & 'TO' \\
\hline , & 'RW' \\
\hline , & 'RH' \\
\hline , & 'US' \\
\hline , & 'E' \\
\hline
\end{tabular}

Origin of fungus

$$
\text { Species Variety }
$$

radish

radish

cauliflower

Copenhagen market

white cabbage

white cabbage

cauliflower

white cabbage

red cabbage

white cabbage

broccoli

white cabbage
Igloo

Copenhagen market

Amager stone head

Erfurter 291

Futura

Haco

Golden Acre

Grusader

Kuusikuu varajanne 
Fig. 3 A. brassicicola

A. tenuissima

Botrytis cinerea

Fusarium moniliforme

$P$. lingam

Rhizoctonia solani

Ulocladium concortiale

Whetzelinia sclerotiorum white cabbage cauliflower white cabbage

red cabbage white cabbage cauliflower white cabbage
Variety

Copenhagen market

Erfurter 986

Golden Acre

Copenhagen market

Langendiger Sommer

Pondus

Erfurter 986

Futura

In addition to the above, preliminary experiments were carried out in 1971 and 1972 on the pathogenicity of A. brassicicola, Fusarium sp., P. lingam and $R$. solani fungi to 'Copenhagen market' cauliflower. One drop per seedling of the undiluted fungal suspension was pipetted onto the seedlings $(4 \times 25)$ grown on sand and the seedlings then kept in isolation for 10 days under plastic sheeting.

\subsection{Seedling raising experiments}

\subsubsection{Effect of fungi on seedling emergence and growth}

In order to determine the importance of seed-borne fungi of cruciferous crop plants, seed infected to varying degrees by different fungi were grown to the seedling stage in plastic pots $(\varnothing=14 \mathrm{~cm})$ using fertilized, fresh peat and sand substrates. Raising was carried out in the laboratory at an illumination of about 3500 lux (low pressure mercury vapour lamp), temperature $20-25^{\circ} \mathrm{C}$ and relative humidity of $40-80 \%$. Some of the seedlings were grown on peat in a greenhouse using plastic seedling boxes $30 \times 45 \mathrm{~cm}$ in size. The seedlings were grown on the sand substrate for 3 weeks and on the peat substrate for 4 weeks. In addition to untreated seeds, similar seeds surface sterilised with $\mathrm{NaClO}$ were also grown on the peat substrate. The effect of surface sterilisation on the fungus content of the seeds used can be seen in Table 5. Surface sterilisation was used in an attempt to obtain seeds which were as healthy as possible but which otherwise would show the same growth characteristics as the diseased seeds. Fungicides were not used instead of surface sterilisation because it was feared that they might affect the development of the seedlings, At the end of the cultivation period the fungi present on the damaged and dead seedlings were examined by keeping the seedlings in moist conditions in petri dishes for 4-6 days. The dryweight of healthy-looking seedlings was determined after drying them for one and a half days at $105^{\circ} \mathrm{C} .4 \times 50$ or $4 \times 100$ seeds per each experimental unit were grown from every seed lot. The seed lots used are listed in Figures 23 and 24 and in Table 6.

In order to determine the importance of seed-borne fungi in causing soilborn damping-off in the peat substrate, the most important and most common seed-borne fungi were mixed into the substrate one week before seeding. Each fungal mycelium, grown for two weeks on PDA medium at room temperature in a petri dish $(\varnothing=9 \mathrm{~cm})$, was mixed with five liters of peat. The fungi was first homogenised in $100 \mathrm{ml}$ of sterile water and then mixed evenly 
throughout the plastic seedling box. A. brassicicola was isolated from 'Crusader' broccoli, P. lingam from 'Langendiger Sommer' red cabbage and Botrytis cinerea from 'Golden Acre' white cabbage. Two rows of 10 seeds each of 'Golden Acre' white cabbage, 'Hama' cauliflower, 'Amager 304' red cabbage and 'Early dwarf' Brussels sprouts were planted in each box. All the seeds used has been shown to be healthy in the seed examination or had been surface sterilised against $A$. brassicicola.

\section{4. 2. Importance of growth substrate}

The effect of steam-treated and untreated Sphagnum peat and fine-sand, with a high mull content, substrates on seed-borne Alternaria brassicicola and Plenodomus lingam was studied by sowing artificially infected cauliflower seeds $(4 \times 25$ seeds per experimental unit) in plastic pots $(\varnothing=14 \mathrm{~cm})$. The seeds were inoculated in the same way as for the pathogenicity tests except that the fungal suspensions were not diluted. A. brassicicola was isolated from 'Crusader' broccoli and P. lingam from 'Urania' cauliflower. The experiment was carried out at a temperature of $20^{\circ} \mathrm{C}$, an illumination level of about 3800 lux and a day-length of $12 \mathrm{~h}$.

The spreading of $A$. brassicicola and P.lingam from diseased seeds to healthy seeds when grown in steam treated mull and fresh peat was studied by sowing healthy cauliflower seeds and cauliflower seeds infected with $A$. brassicicola and $P$. lingam in differently spaced rows in seedling boxes. The fungal isolates and inoculation method were the same as those described earlier.

\section{4. 3. Effect of temperature on damping-off and growth}

The effect of cultivation temperature on damping-off and reduction in growth caused by seed-borne Alternaria brassicicola and Plenodomus lingam were studied in three different experiments. Two cultivation temperatures were used: high $-18^{\circ} \mathrm{C}$ at night $(8 \mathrm{~h})$ and $25^{\circ} \mathrm{C}$ during the day $(16 \mathrm{~h})$ and low $-8^{\circ} \mathrm{C}$ at night $(8 \mathrm{~h})$ and $15^{\circ} \mathrm{C}$ during the day $(16 \mathrm{~h})$. In the first experiment, seed lots infected to varying degrees with $A$. brassicicola were grown in sterile sand. 6 lots of white cabbage, 1 lot of red cabbage and 1 lot of marrow kale seeds were studied. In the second experiment, red cabbage seeds strongly infected $(13.4 \%)$ with $P$. lingam were grown in sterile sand. In the third experiment, untreated and surface sterilised white cabbage, cauliflower and red cabbage seeds were grown in the peat substrate. $4 \times 50$ seeds from each seed lot were planted in pots $(\varnothing=14 \mathrm{~cm})$ in each experiment. The pots were kept in a Vötsch growth chamber where the relative humidity of the air was $90-95 \%$.

\section{5. Control experiments}

In order to determine the effect of the thiram dressing and substrate treatments used in Finland during seedling raising against Alternaria brassiscicola, severely infected seeds of white cabbage, cauliflower and red cabbage were treated with a preparation of Pomarsol Forte (80\% thiram) at a dosage level of $35 \mathrm{~g} / 10 \mathrm{~kg}$ seeds. The substrate was sprayed two days before and four days 
after seeding with the same preparation at a dosage level of $5 \mathrm{~g} / \mathrm{m}^{2}$. In addition to untreated and the different treatments, surface sterilised seeds of the same seed lots, which represented healthy seeds, were included in the experiment. $3 \times 300$ seeds per each experimental unit were sown in plastic boxes in peat.

\section{6. Statistical methods}

In Tables 1, 3 and 4, healthy percentage refers to the mean number of completely healthy seeds of all the lots and total fungicity- $\%$ the mean value of the fungus content- $\%$ of all the lots. Fungus content- $\%$ refers to the number of fungi observed in the seeds examined. Damping-off before emergence, referred to in Figure 22, is the difference between the germination- $\%$ and emergence-\%. Differences in health, total fungicity and fungus content between different plant species and cultivars have been tested with variance analysis. The dependance between germination percentage and degree of fungal infection has been tested, when necessary, by means of the coefficient of correlation. The difference between the fungus content of germinated and ungerminated seeds and dead and living seedlings ten days after sowing have been tested using the t-test.

The effect of Alternaria brassicicola- $\%$ in the seeds on the ratio between seedling mortality- $\%$ and $A$. brassicisola- $\%$, which is a variable for the infection density of the seed at different fungus contents, and on the mortality of different white cabbage and red cabbage varieties in the Jacobsen germinator 10 days after seeding have been described using a straight regression line, of the form $\mathrm{y}=\mathrm{a}+\mathrm{bx}$, or a curved regression line, of the form $\mathrm{y}=a \mathrm{e}^{\beta^{\mathrm{x}}}$. The figure has been chosen on the basis of the superiority of the coefficient of correlation.

Whenever necessary, the results of the pathogenicity, seedling raising and control experiments have been tested using the t-test, variance analysis or regression line and regression curve.

Significance of the statistical tests are given as follows:

$$
x>t_{0.05} x x>t_{0.01} \text { and } x x x>t_{0.001} .
$$

\section{Seed borne fungi of crucifererous cultivated plants}

The content of healthy seeds, i.e. health- $\%$, varied considerably between plant species (Table 1). The health-\% of white cabbage, red cabbage, marrow kale, Brussels sprouts and rape seeds were lower than those of other species. Kohl-rabi and broccoli seeds were especially healthy. The sum of total fungicity- $\%$ and health- $\%$ was more than $100 \%$ in many species since more than one species of fungus was frequently present in the same seed.

There was slight negative correlation between health- $\%$ and germination- $\%$ (Table 1). There were significant differences between the types of fungi present on the different plant species. They are presented in more detail in later chapters. 


\section{1. Asomycotina}

Of the plant diseases affecting cruciferous plants caused, according to the literature, by Ascomycotina, the fungus Mycosphaerella brassicicola (Duby) Lind was not found in this study. This fungus can penetrate the siliquae and reach the seed of seed crops and thus spread ring spot of cruciferous plants to the young seedlings (HUBER and GouLD 1949).

\section{Pleospora herbarum (Pers.) Rabenborst}

$P$. herbarum, the conidial stage of which is Stemphylium botryosum Wallr., is found almost everywhere in the world as a saprophyte or weak plant parasite. The fungus is of little economic importance. It causes leaf spot on a few plants, such as lettuce, red clover and tomato. $P$. herbarum is frequently found on onion leaves killed or weakened by Peronospora destructor (Berk.) Caspary (NeErganRd 1945).

$P$. herbarum is a common seed-borne fungus on vegetable, ornamental, cereal, grass and leguminous plants (Groves and Skolko 1944 a, NeergaArd 1945, YlimäKi 1970, MãKelä 1972, SALONEN 1972). It usually occurs on the seeds of cruciferous plants in small amounts (Croves and Skolko 1944 a, Neergatrd 1945). P. herbarum is a weak pathogen of cabbage (NEERgaARd 1945).

$P$. herbarum was found only rarely on the seeds of white cabbage, cauliflower, broccoli, Brussels sprouts, swede, turnip and radish. The fungus content of the seed lots varied from 0.5 to $3.5 \%$. During germination in the Jacobsen germinator the fungi formed conidial stages only (Fig. 16). The fungus produced its perfect stage when cultivated by the agar method (Fig. 17).

During the time when the health inspection was carried out, $P$. herbarum was not found alone in any of the damaged or dead seedlings, but remained under the seed coat during germination. The fungus was found on damaged seedlings in the emergence experiments, but in this case only on wilted cotyledons together with other fungi. The fungus was never found alone in damped-off seedlings.

\section{Whetzelinia sclerotiorum (Lib.) Korf \& Doumont}

There is very little information in the literature about the occurrence of W. sclerotionum (syn. Sclerotinia sclerotiorum (Lib.) de Bary) on the seeds of cruciferous plants. Sclerotia can be found mixed in with the seeds (Mclean 1949) or present in the seeds as mycelium (Pound et al. 1951, NeErganird 1958 b). W. sclerotionum can affect cabbage seed cultivation by damaging the flowering shoot and inflorescences (MCLeAn 1958). ANDERSEN (1970) found the fungus three times from 189 seed lots inspected.

$W$. sclerotiorum was found in this study in one lot of cauliflower seeds in the mycelium stage at a content of less than $1 \%$. The fungus was slightly pathogenic to white cabbage (Fig. 3).

\section{2. Deuteromycotina}

\section{Alternaria brassicae (Berk.) Sacc.}

A. brassicae (syn.: Macrosporium brassicae Berk., full synonyms are given by WILTSHIRE (1947)) is distributed over all European countries, America and other regions where cabbage is grown (NEERgaARD 1945). 
The fungus is seed-borne. On leaves of various Cruciferae it forms circular, zonate, light brown to greyish or dark spots from less than $0.5-12 \mathrm{~mm}$ in diameter, sometimes coalescing. On the mid-ribs of the leaves the spots are oblong or linear, sunken and on the heads of cauliflower black spots are formed (Ellis 1971). Seedlings attacked by the fungus developed damping-off: in the germinator the attack as a rule commences on the root and then extends up along the stem and leaves, with development of a yellowish-brown rot or numerous brown spots (NeERgaArd 1945). Host plants include broccoli, white cabbage, cauliflower, horseradish, kohlrabi, mustard, radish and turnip (Ellis 1971). NeERgaArd (1945) has listed other plants on which the fungus has been reported or which have been susceptible to it in pathogenicity tests. There is very little mention in the literature of the economic importance of A. brassicae, apart from its effect on rape. WeIMER (1926), who studied the occurrence of this fungus in the USA, found that the lower leaves of cauliflower and cabbage were so badly damaged that the size of the crop was significantly reduced. The fungus can cause tuber rot of turnip which continues to cause damage during storage (CHUPP 1935). A. brassicae causes serious infection of the siliqua of rape during exceptionally wet and warm summers (Domsch 1957, Louvet 1958, Loof 1959, MCDonald 1959). The outbreak of a serious epidemic presupposes a moisture level of $95-100 \%$ for at least $38 \mathrm{~h}$ and a temperature of $21-27^{\circ} \mathrm{C}$ for three days in succession (Dомsch 1957). A high degree of seed infection reduces the size of the seed and yield and causes damping-off (McDonald 1959). In the production of cabbage seed, the fungus, together with $A$. brassicicola, attacks the inflorescences causing a reduction in yield and in the quality of the seeds (NIELSEN 1933).

The fungus forms a $3-8 \mu$ thick, septate mycelium which is initially light in colour but later becomes yellowish-brown. The conidiophores are yellowishbrown or dark yellow-brown, septate, unbranched upright, $15-50 \mu$ long and $6-10 \mu$ wide on the host plant. The condiophores were considerably longer, over $20 \mu$, when grown on PDA-medium than on the host plant. The conidia were formed singly on the host plant, but in chains of $2-3$ conidia on PDA medium. The conidia are smooth, light or dark brown, elongated with an extended beak at one end (Fig. 10 a). The size of the conidium is $90 \mu$ $(50-175 \mu) \times 20 \mu(14-38 \mu)$ on the host plant and $76 \mu(50-100 \mu) \times 20 \mu$ $(15-30 \mu)$ on the PDA medium, not counting the beak, which is $60 \mu(25-$ $140 \mu)$ long and $7 \mu(5-8 \mu)$ thick on the host plant and $45 \mu(25-80 \mu)$ long and $6 \mu(5-7 \mu)$ thick on the PDA medium. In conidia there are 6-15 septa in the transverse direction and $0-7$ in the longitudinal direction. The size of the conidium is the same as in the literature (NEERGAARD 1945).

A. brassicae occurred in five white cabbage, one kale and four rape seed lots at fungus contents of $0.5-6.5 \%$. Of the infected white cabbage lots, two of them were found using the agar method only.

During germination, the fungus grew from the seed coat to the hypocotyl and killed the seedling. In the pathogenicity tests $A$. brassicae seriously damaged the seedlings of cauliflower within 14 days after sowing (Fig. 3).

\section{Alternaria brassicicola (Schw.) Wiltshire}

A. brassicicola (syn.: Helminthosporium brassicicola Schweinitz, Macrosporium cheiranthi Fr. var. circinans Berk. \& Curt., Alternaria circinans (Berk. \& Curt.) Bolle, Alternaria oleraceae Milbraith, full synonyms are given by WILTHSHIRE (1947)) is widely distributed in Europe and the USA where it not infrequently causes considerable damage to cruciferous crops (NEERGAARD 1945). The fungus is also found in Australia, Burma, Canada, Ceylon, Cyprus, Ethiopia, Ghana, Guinea, Hong Kong, India, Jamaica, Japan, Libya, Malawi, Malaya, Mauritius, Nepal, New Guinea, New Zealand, Nigeria, Rhodesia, Rumania, Sabah, Sierra Leone, South Africa, 
Sudan, Tanzania, Turkey, Uganda and Zambia (Ellis 1971). In Finland, A. brassicicola has been found by LinNasalmi (1954) on cauliflower, white cabbage and china aster seedlings.

The fungus is seed-borne. It is a pronounced cruciferous parasite. Most often the fungus is encountered on cabbage, but undoubtedly it attacks all species of Cruciferae. In a number of cases $A$. brassiciola has been found on species outside the crucifers (NEERgaARD 1945).

On full-grown plants the fungus attacks the outer leaves in particular. It induces leaf spots which appear as small dark-coloured areas which spread rapidly to form circular lesions up to $1 \mathrm{~cm}$ in diameter. In humid weather groups of dark conidiophores become visible to the eye on the surface of the lesions, and they are often arranged in concentric rings. Finally, the leaves dry. Both $A$. brassicae and $A$. brassicicola affect cabbage heads chiefly after harvest. In long storage they overrun the outer leaves and sporulate profusely, giving a black, mouldy appearance necessitating excessive trimming (NEergaArd 1945, WALKER 1952). Cauliflower curds are also affected with the small-spot form (WEIMER 1924). In seedling plants, soon after flowering, the fungus reaches the flower stalks and the siliques, on which they produce numerous dark violet to brownish dot, stains which gradually become confluent, forming large necrotic areas. All the parts of the plants are liable to attack by the fungus so that the entire seed field, under conditions favourable to the fungus, may change colour within a few days from green to brown or almost black. The attacked silique dry and the siliques then open long before the normal term (NeERgaARd 1945).

On seedlings the fungus produces brown necrotic streaks and spots on the stem and cotyledons, and under particularly favourable development conditions, typical symptoms of damping-off.

The attack of the fungus in the form of leaf spots on plants in the field is rarely of any particular significance. As a rule it is chiefly the old and weakened leaves that are damaged. On cabbage under transport or in storage, however, the fungus may be able to spread to such an extent that it causes a considerable financial loss. On heads of cauliflower the fungus may produce numerous rot spots making the heads unusable (WEIMER 1924). The greatest economical significance, however, is to be attached to the often quite violent attacks of almost explosive development on the seed crops of crucifers towerds the time for maturing of the seeds. Here the fungus lowers the yield of seed quantitatively as well as qualitatively, and in severe cases the crop may even be destroyed completely. In a laboratory analysis of the germinative capacity of the seed, the seeds which are badly attacked will not germinate at all, or will give merely a weak seedling which is either killed at once by the fungus or develops as an abnormal seedling.

With germination in soil, the injuries caused by the fungus may also sometimes produce a marked decrease in the germinating capacity of the seed, whereas the role of the fungus in production of damping-off is of practical significance but very seldom (NIELSEN 1933).

The fungus forms branched, septate, $2-7 \mu$ thick mycelia which are initially light coloured, later brown or olive-brown. The conidiophores are dark olive-brown or almost violet-brown, septate, branched or unbranched, usually slightly swollen at the tip, $20-60 \mu$ long and $5-8 \mu$ thick. The conidia (Fig. 9) are formed in chains. They are smooth, slightly club-shaped or truncated or even stretched at one end to form a tapered, short beak. The conidia are usually regular and symmetrical along their longitudinal axis. Their colour varies from yellowish brown to almost black. The size of the conida on the hostplant is $38 \mu(14-78 \mu) \times 13 \mu(6-30 \mu)$. There are usually $1-6$ transverse septa. Transverse septa are rarely formed in young samples, but in old ones there may be as many as six. The conidia on PDA-medium are slightly smaller, $27 \mu(10-47 \mu) \times 9 \mu(6-17 \mu)$, than those on the host-plant. The size of the conidium is the same as in the literature (NEERGAARD 1945).

A. brassicicola was the most common seed-borne pathogen on the cruciferous plants. $90-100 \%$ of the white cabbage, red cabbage, kale, Brussels sprouts 


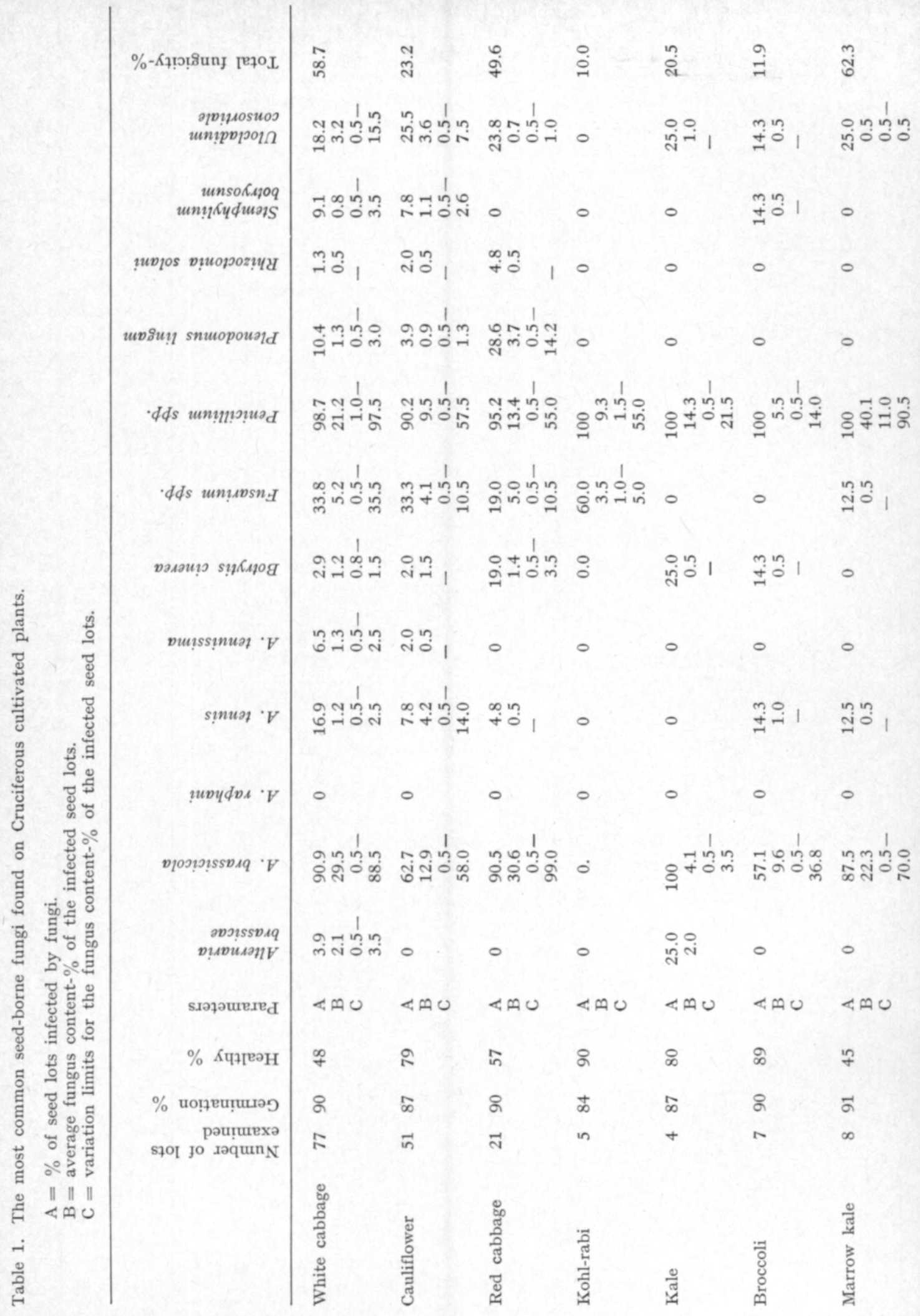


in

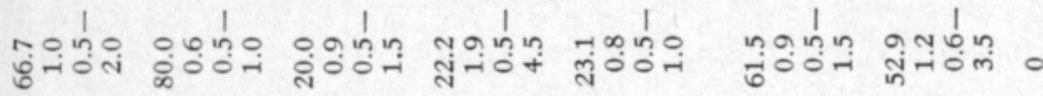

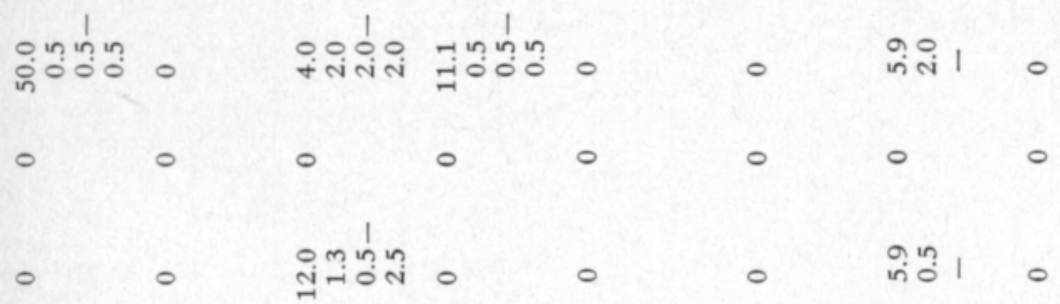

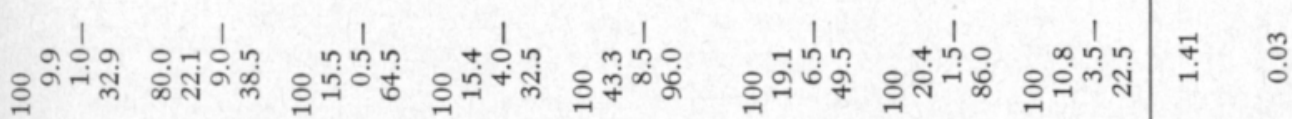

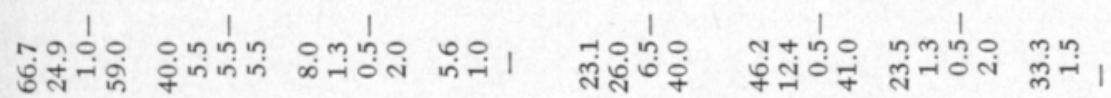

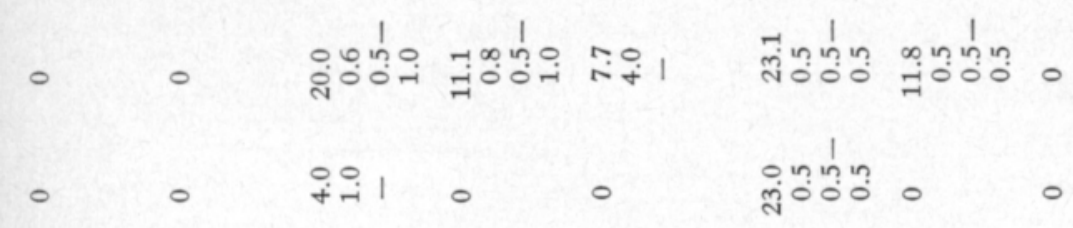

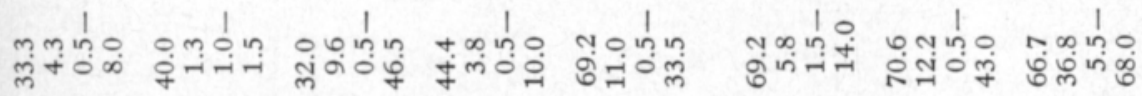

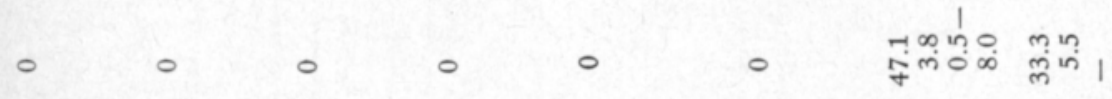

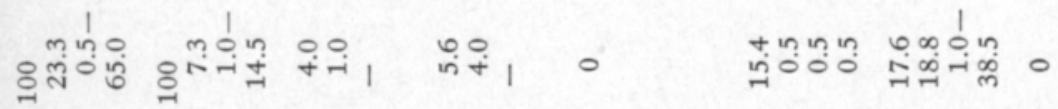

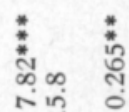
mingo:

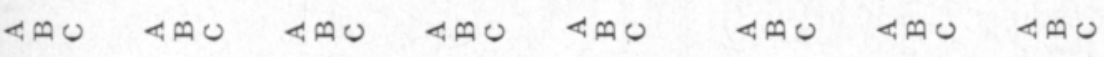

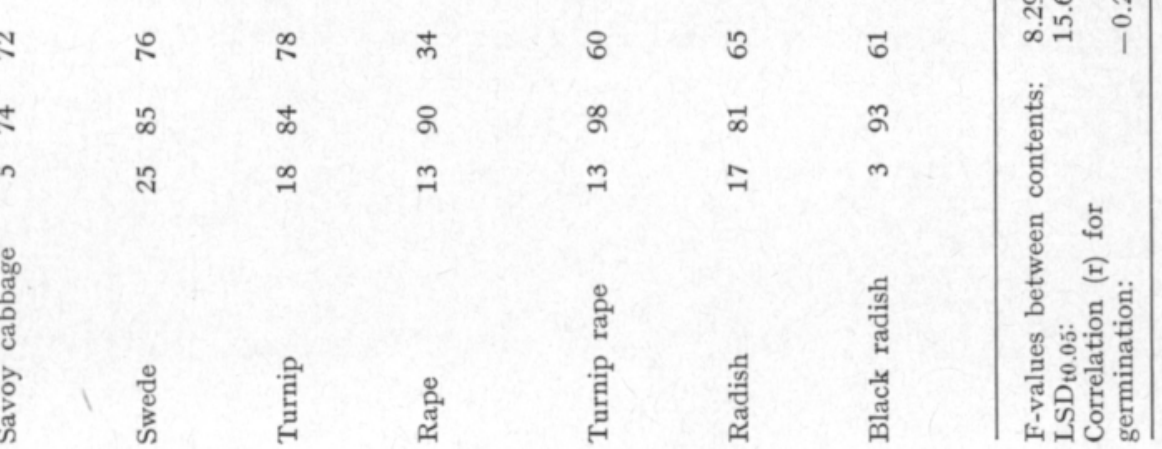


and savoy cabbage seed lots were infected. This fungus did not occur in any of the kohl-rabi, rape and black radish seed lots. There was one infected lot of swede seeds and one of turnip. The number of infected seed lots of other plants varied from $\mathbf{1 5 - 8 8 \%}$. The degree of infection in the infected seed lots of kale, broccoli, savoy cabbage, swede, turnip and turnip rape were significantly lower than that in any other of the plants studied. White cabbage, red cabbage, marrow kale and Brussels sprouts seed lots were the most severely infected. The highest fungus contents were $65-99 \%$. There was positive correlation between the germination perccentage and the $\mathrm{A}$. brassicicola content (table 1).

A. brassicicola was just as common on germinated as on ungerminated seeds of all the plant species studied. Ten days after sowing, the fungus was more common, at the $1 \%$ risk level, on dead than on living seedlings (Table 2). Of the different white cabbage varieties, Faales Blåtopp and Futura were the most diseased, on the average $64 \%$ of the latter variety being infected (Table $3)$. There was no statistically sifnificant difference between the fungus content of the different cauliflower varieties (Table 4).

In the pathogenicity tests, the damage caused by $A$. brassiciola 7 days after sowing was less on the turnip seedlings than on cauliflower, swede, radish and turnip rape seedlings. After 10 days, however, there was no longer any apparent difference between the resistance of the different plant species (Fig. 1). Of the different cabbage species, white cabbage and kale were the

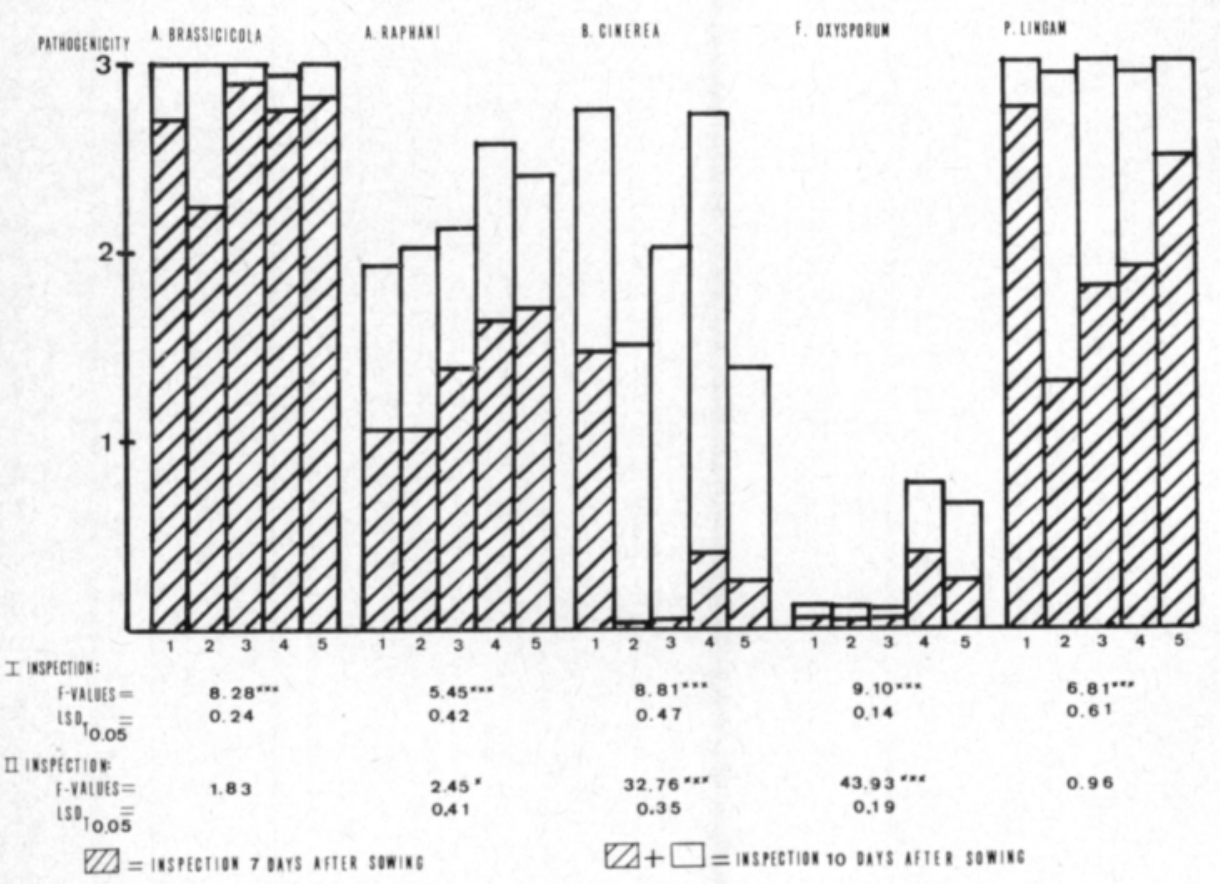

Fig. 1. Pathogenicity of Alternaria brassicicola, Alternaria raphani, Botrytis cinerea, Fusarium oxysporum and Plenodomus lingam on 'Hama' cauliflower (1), 'Mustiala' swede (2), 'Östersundom' turnip (3), 'Saxa' radish (4) and 'Torpe' turnip rape (5). 
Table 2. Occurrence of some of the most common seed-borne fungi of Cruciferous cultivated plants 10 days after sowing. Mean values of the infected lots are expressed as number-\%.
$A=$ germinated seeds
$\mathrm{B}=$ ungerminated seeds
$\mathrm{C}=$ living seedlings
$\mathrm{D}=$ dead seedlings

\begin{tabular}{|c|c|c|c|c|c|c|c|c|c|}
\hline & \multirow[b]{2}{*}{ 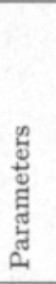 } & \multirow[b]{2}{*}{ 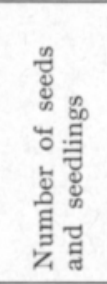 } & \multicolumn{7}{|c|}{ number- $\%$} \\
\hline & & & 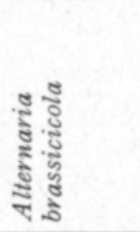 & 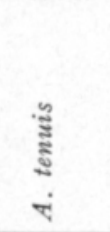 & 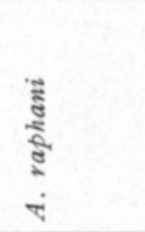 & 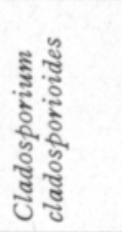 & 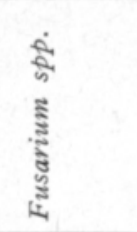 & 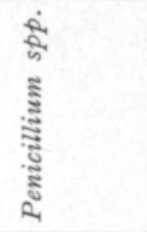 & 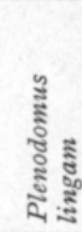 \\
\hline \multirow{4}{*}{$\begin{array}{l}\text { White and red } \\
\text { cabbage }\end{array}$} & A & 20686 & 30.6 & - & - & - & 3.4 & 17.0 & 2.6 \\
\hline & B & 2391 & 38.1 & & & & 14.6 & 29.1 & 7.5 \\
\hline & $\mathrm{C}$ & 17773 & 22.6 & & & & 2.6 & 21.6 & 0.6 \\
\hline & D & 2913 & $92 \cdot 4$ & & & & 1.3 & 15.6 & 23.2 \\
\hline \multirow{2}{*}{$\begin{array}{r}\text { t-values: } A \text { and } B \\
\text { C and D }\end{array}$} & & & 1.58 & & & & $3.12 * *$ & $3.22 * * *$ & 0.87 \\
\hline & & & $24.3^{* * *}$ & & & & 1.29 & 1.81 & 1.67 \\
\hline \multirow[t]{4}{*}{ Cauliflower } & A & 9830 & 13.0 & - & - & - & 2.3 & 6.4 & - \\
\hline & B & 1470 & 17.1 & & & & 22.5 & 16.4 & \\
\hline & $\mathrm{C}$ & 9099 & 6.3 & & & & 3.2 & 12.9 & \\
\hline & D & 731 & 93.3 & & & & 0.0 & 13.3 & \\
\hline \multirow{2}{*}{\multicolumn{2}{|c|}{$\begin{aligned} \text { t-values: } & A \text { and } B \\
& C \text { and } D\end{aligned}$}} & & 0.53 & & & & $3.6 * *$ & $2.49^{*}$ & \\
\hline & & & $23.4^{* * *}$ & & & & $5.02^{* * *}$ & 0.09 & \\
\hline \multirow[t]{4}{*}{ Other cabbages } & A & 6690 & 18.1 & - & - & - & 12.6 & 12.5 & - \\
\hline & B & 1104 & 20.3 & & & & 37.3 & 27.6 & \\
\hline & $\mathrm{C}$ & 6210 & 10.2 & & & & 12.4 & 20.0 & \\
\hline & $\mathrm{D}$ & 480 & 81.5 & & & & 19.1 & 18.2 & \\
\hline \multirow{2}{*}{\multicolumn{2}{|c|}{$\begin{array}{r}\text { t-values: } \mathrm{A} \text { and } \mathrm{B} \\
\mathrm{C} \text { and } \mathrm{D}\end{array}$}} & & 0.29 & & & & 2.02 & $3.21 * *$ & \\
\hline & & & $9.67^{* * *}$ & & & & 0.44 & 0.21 & \\
\hline \multirow{4}{*}{$\begin{array}{l}\text { Rape and } \\
\text { turnip rape }\end{array}$} & A & 4876 & - & 8.5 & - & 10.8 & - & 30.9 & - \\
\hline & B & 324 & & 10.2 & & 11.8 & & 49.4 & \\
\hline & $\mathrm{C}$ & 4642 & - & 8.1 & & 12.4 & & 33.5 & \\
\hline & D & 234 & & 13.3 & & 3.2 & & 42.3 & \\
\hline \multirow{2}{*}{\multicolumn{2}{|c|}{$\begin{array}{r}\text { t-values: } \mathrm{A} \text { and } \mathrm{B} \\
\mathrm{C} \text { and } \mathrm{D}\end{array}$}} & & & 0.32 & & 0.22 & & $2.39^{*}$ & \\
\hline & & & & 1.4 & & $2.56^{*}$ & & 0.88 & \\
\hline \multirow[t]{4}{*}{ Swede and turnip } & A & 7285 & - & 5.6 & - & 6.8 & - & 12.6 & - \\
\hline & B & 1315 & & 8.9 & & 8.52 & & 26.3 & \\
\hline & $\mathrm{C}$ & 7193 & & 6.7 & & 9.7 & & 13.7 & \\
\hline & $\mathrm{D}$ & 92 & & 19.8 & & 10.4 & & 40.7 & \\
\hline \multirow{2}{*}{\multicolumn{2}{|c|}{$\begin{array}{r}\text { t-values: } \mathrm{A} \text { and } \mathrm{B} \\
\mathrm{C} \text { and } \mathrm{D}\end{array}$}} & & & 0.76 & & 0.4 & & $3.88^{* * *}$ & \\
\hline & & & & 1.63 & & 0.11 & & $2.88^{* *}$ & \\
\hline Radish and & A & 3315 & - & 15.3 & 10.0 & 2.6 & - & 14.8 & - \\
\hline \multirow[t]{3}{*}{ black radish } & B & 685 & & 8.7 & 4.6 & 5.3 & & 19.2 & \\
\hline & $\mathrm{C}$ & 3150 & & 16.3 & 7.1 & 4.2 & & 13.9 & \\
\hline & $\mathrm{D}$ & 165 & & 32.9 & 57.3 & 0.6 & & 13.2 & \\
\hline \multirow{2}{*}{$\begin{array}{r}\text { t-values: } \mathrm{A} \text { and } \mathrm{B} \\
\mathrm{C} \text { and D }\end{array}$} & & & & 0.83 & 1.03 & 0.92 & & 0.62 & \\
\hline & & & & 1.1 & $4.56 * * *$ & 1.19 & & 0.56 & \\
\hline
\end{tabular}


Table 3. The most common seed-borne fungi of the white cabbage varieties most frequently cultivated.

$\mathrm{A}=$ percentage of seed lots infected by fungi.

$\mathrm{B}=$ average fungus content- $\%$ of the infected seed lots.

$\mathrm{C}=$ variation limits for the fungus content- $\%$ of the infected seed lots.

\begin{tabular}{|c|c|c|c|c|c|c|c|c|c|c|c|}
\hline Variety & 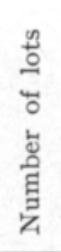 & 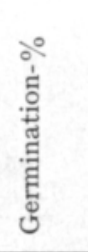 & 咅 & 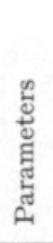 & 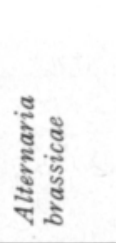 & 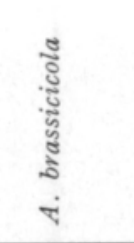 & $\begin{array}{l}\cong \\
\text { जू๊ } \\
\dot{\nabla}\end{array}$ & $\begin{array}{l}\text { हो } \\
\text { के } \\
\text { है } \\
\text { जू }\end{array}$ & 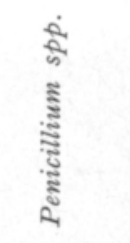 & 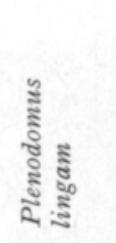 & 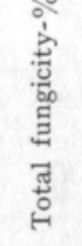 \\
\hline $\begin{array}{l}\text { Ditmarsker } \\
\text { No } 84\end{array}$ & 9 & 91.8 & 48.0 & $\begin{array}{l}\text { A } \\
\text { B } \\
\text { C }\end{array}$ & $\begin{array}{l}11 \\
0.2 \\
-\end{array}$ & $\begin{array}{c}100 \\
21.0 \\
3.0- \\
32.2\end{array}$ & $\begin{array}{l}22 \\
1.3 \\
1.0- \\
1.5\end{array}$ & $\begin{array}{l}22 \\
1.5 \\
0.5- \\
2.5\end{array}$ & $\begin{array}{l}100 \\
20.2 \\
4.5- \\
63.5\end{array}$ & $\begin{array}{l}22 \\
1.2 \\
1.0- \\
1.3\end{array}$ & 53.5 \\
\hline Faales Blåtopp & 10 & 87.7 & 43.0 & $\begin{array}{l}\text { A } \\
\text { B } \\
\text { C }\end{array}$ & 0 & \begin{tabular}{r}
\multicolumn{1}{c}{80} \\
40.1 \\
1.5 \\
73.5
\end{tabular} & $\begin{array}{l}30 \\
1.2 \\
0.5- \\
2.5\end{array}$ & $\begin{array}{l}40 \\
6.4 \\
0.5- \\
20.5\end{array}$ & $\begin{array}{c}100 \\
16.4 \\
2.0- \\
42.0\end{array}$ & $\begin{array}{c}10 \\
0.5 \\
-\end{array}$ & 60.5 \\
\hline Futura & 6 & 89.7 & 29.4 & $\begin{array}{l}\mathrm{A} \\
\mathrm{B} \\
\mathrm{C}\end{array}$ & 0 & $\begin{array}{l}100 \\
64.3 \\
42.5 \\
86.0\end{array}$ & 0 & $\begin{array}{l}50 \\
2.7 \\
0.5- \\
5.5\end{array}$ & $\begin{array}{c}100 \\
5.0 \\
1.0- \\
10.5\end{array}$ & 0 & 74.0 \\
\hline Colden Acre & 11 & 92.7 & 49.3 & $\begin{array}{l}\text { A } \\
\text { B } \\
\text { C }\end{array}$ & $\begin{array}{l}9 \\
0.2 \\
-\end{array}$ & $\begin{array}{l}90 \\
11.1 \\
0.5- \\
44.0\end{array}$ & $\begin{array}{l}27 \\
0.5 \\
0.5- \\
0.5\end{array}$ & $\begin{array}{c}9 \\
20.5 \\
-\end{array}$ & $\begin{array}{l}100 \\
21.3 \\
3.0- \\
53.0\end{array}$ & $\begin{array}{l}18 \\
2.3 \\
1.5- \\
3.0\end{array}$ & 42.4 \\
\hline $\begin{array}{l}\text { Copenhagen } \\
\text { market }\end{array}$ & 12 & 91.9 & 51.0 & $\begin{array}{l}\mathrm{A} \\
\mathrm{B} \\
\mathrm{C}\end{array}$ & $\begin{array}{l}17 \\
2.0 \\
0.5- \\
3.5\end{array}$ & $\begin{array}{l}75 \\
38.5 \\
1.0- \\
86.0\end{array}$ & $\begin{array}{l}8 \\
4.5 \\
-\end{array}$ & $\begin{array}{l}42 \\
8.2 \\
0.5- \\
35.5\end{array}$ & $\begin{array}{l}92 \\
15.3 \\
1.0- \\
53.0\end{array}$ & 0 & 57.9 \\
\hline Länsipohja & 8 & 91.4 & 56.2 & $\begin{array}{l}\text { A } \\
\text { B } \\
\text { C }\end{array}$ & $\begin{array}{c}13 \\
0.2 \\
-\end{array}$ & $\begin{array}{c}100 \\
18.5 \\
1.5- \\
48.0\end{array}$ & $\begin{array}{l}13 \\
1.0 \\
-\end{array}$ & 0 & $\begin{array}{c}100 \\
24.0 \\
1.0- \\
64.5\end{array}$ & $\begin{array}{c}13 \\
0.5 \\
-\end{array}$ & 60.3 \\
\hline $\begin{array}{l}\text { Ruhm von } \\
\text { Enkhuizen }\end{array}$ & 11 & 88.2 & 19 & $\begin{array}{l}\text { A } \\
\text { B } \\
\text { C }\end{array}$ & $\begin{array}{l}9 \\
2.3 \\
-\end{array}$ & $\begin{array}{l}82 \\
18.8 \\
1.0- \\
88.5\end{array}$ & $\begin{array}{l}9 \\
1.3 \\
-\end{array}$ & $\begin{array}{l}46 \\
1.3 \\
0.5- \\
2.5\end{array}$ & $\begin{array}{c}100 \\
39.5 \\
2.0- \\
97.5\end{array}$ & $\begin{array}{l}18 \\
1.1 \\
0.2- \\
2.0\end{array}$ & 67.2 \\
\hline $\begin{array}{l}\text { Correlation }(r) \text { fo } \\
\text { germination: }\end{array}$ & & & $0.243^{*}$ & & & 0.125 & & -0.354 & 0.123 & & 0.22 \\
\hline
\end{tabular}


Table 4. The most common seed-borne fungi of the cauliflower varieties most frequently cultivated.

$A=$ percentage of seed lots infected by fungi.

$\mathrm{B}=$ average fungus content- $\%$ of the infected seed lots.

$\mathrm{C}=$ variation limits for the fungus content- $\%$ of the infected seed lots.

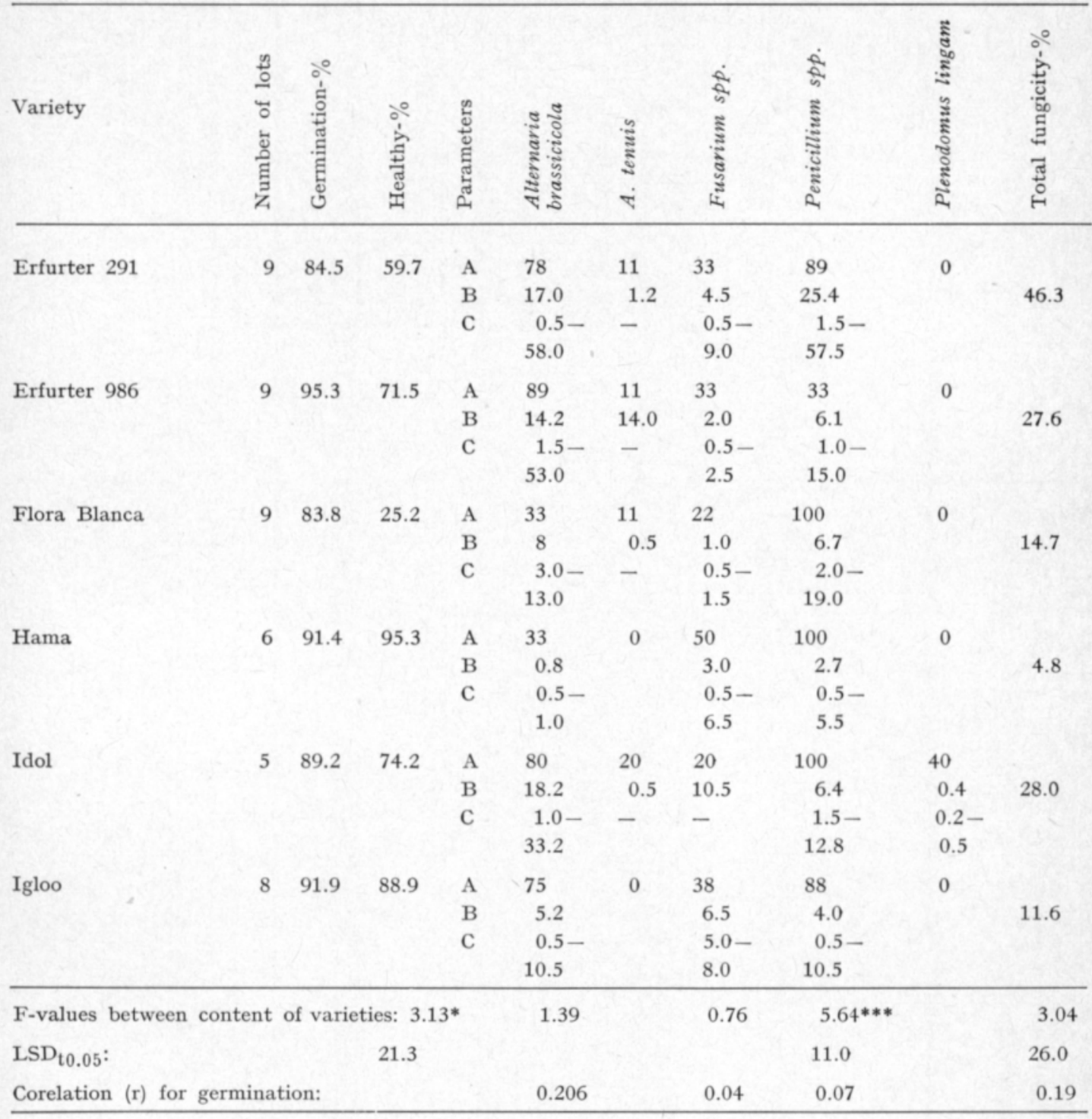

most susceptible. Of the different $A$. brassicicola isolates, the one isolated from Estonian white cabbage seed appeared to be the most pathogenic (Fig. 2).

In the health inspection carried out on a Jacobsen germinator, the seedling mortality of Faales Blåtopp and Länsipohja white cabbage varieties increased more slowly than that of the other varieties as the A. brassicicola content increased (Fig. 4). The ratio between the seedling mortality and $A$. brassicicola content of the seed lots with $5 \%$ or more $A$. brassicicola out of the whole seed 


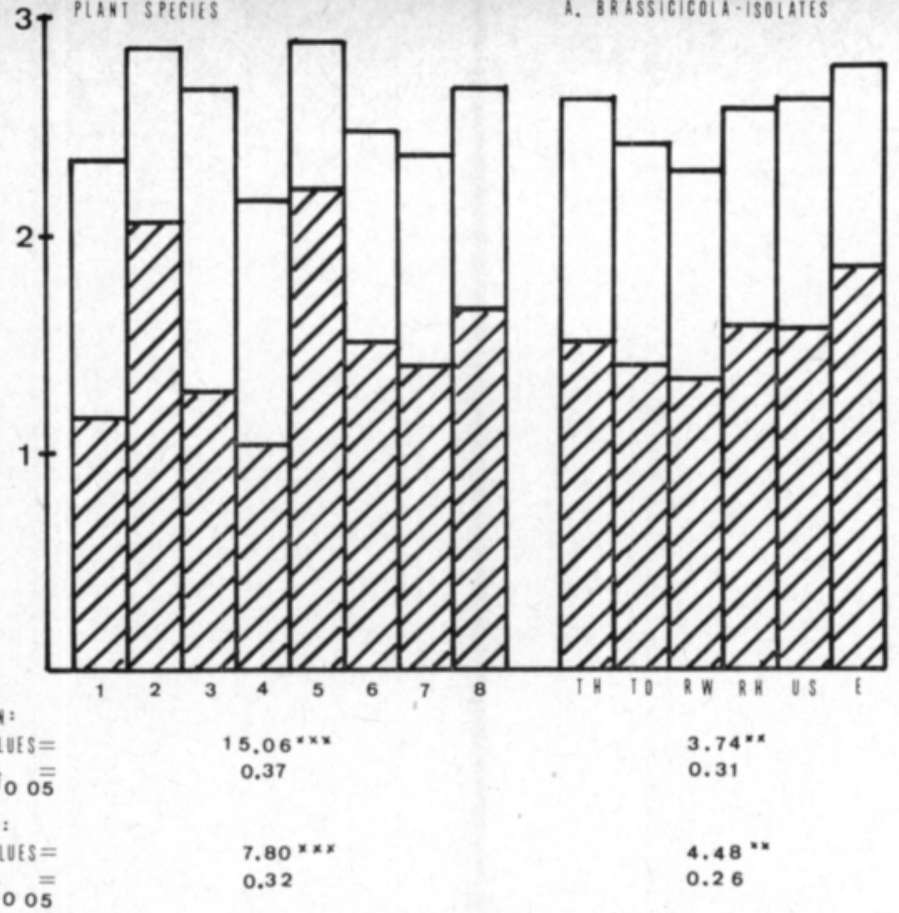

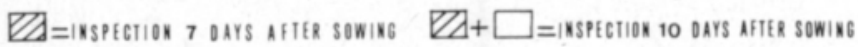

Fig. 2. The resistance of different species of cabbage against Alternaria brassicicola as the mean for 6 isolates and the pathogenicity of different $A$. brassicicola isolates as the mean for 8 species of cabbage.

$1=$ 'Amager 304' red cabbage, $2=$ 'Golden Acre' white cabbage, $3=$ 'Greenia' broccoli, $4=$ 'Early dwarf' Brussels sprouts, $\mathbf{5}=$ 'Half high' kale, $6=$ 'White wiener' Kohl-rabi, $7=$ 'U.mer' Savoy cabbage, $8=$ 'Hama' cauliflower, A. brassicicola isolates: $\mathrm{TH}=$ Denmark, $\mathrm{TO}=$ Denmark, $\mathrm{RW}=$ Sweden, $\mathrm{RH}=$ Sweden, $\mathrm{US}=\mathrm{USA}$ and $\mathrm{E}=$ Estonian.
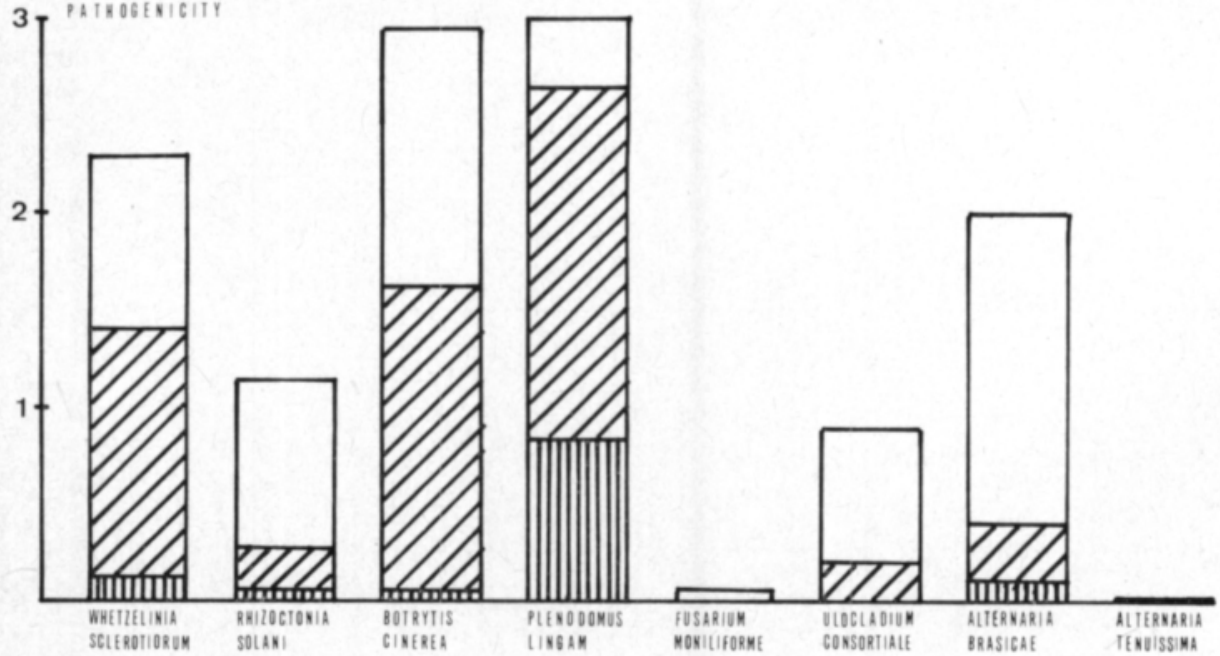

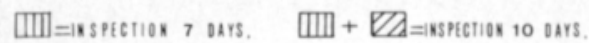

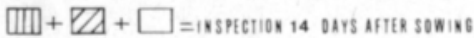

Fig. 3. The pathogenicity of different seed-borne fungi on'Hama' cauliflower. 


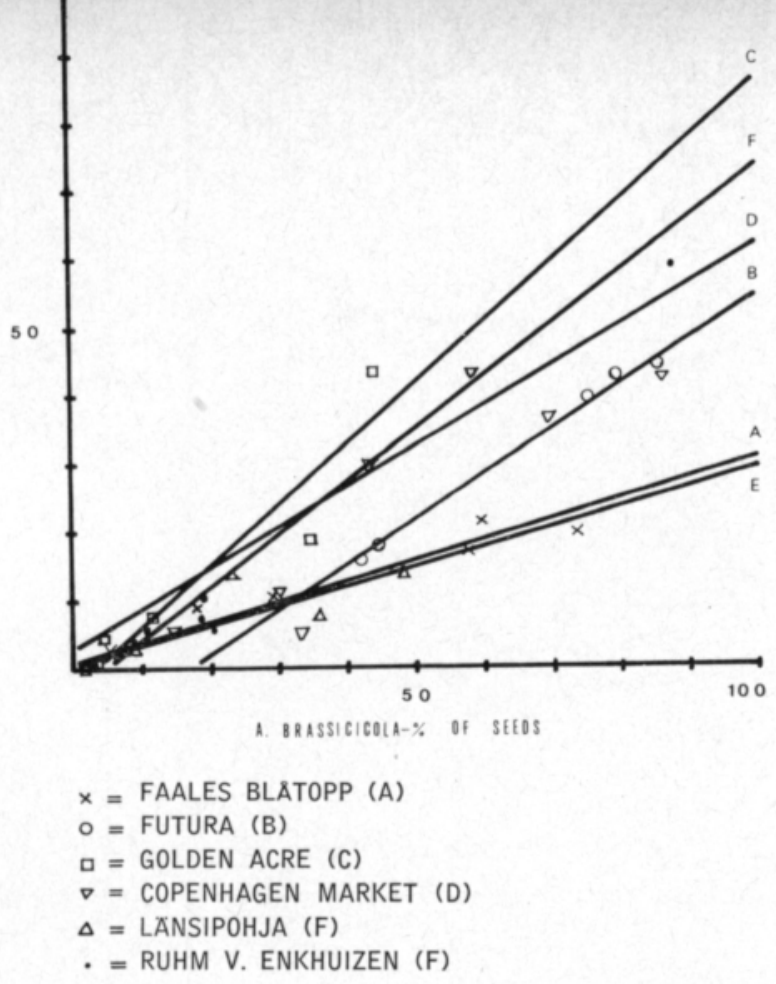

Fig. 4. The effect of seed-borne Alternaria brassicicola on the seedling mortality of different varieties of white cabbage 10 days after sowing on a Jacobsen germinator.

$\mathrm{A}=$ Faales Blåtopp: $\mathrm{y}=1.29$

$+0.289 \mathrm{x}, \mathrm{r}=0.96 \mathrm{xx}$

$\mathrm{B}=$ Futura: $\mathrm{y}=-11.94+$ $0.668 x, r=0.99 x x$

$\mathrm{C}=$ Golden Acre: $\mathrm{y}=-2.90+$ $0.886 \mathrm{x}, \mathrm{r}=0.97 \times \mathrm{x}$

$\mathrm{D}=$ Copenhagen market; $\mathrm{y}=$ $2.95+0.593 \mathbf{x}, \mathrm{r}=0.92 \times \mathbf{x}$

$\mathrm{E}=$ Länsipohja: $\mathrm{y}=1.39+$ $0.286 \mathrm{x}, \mathrm{r}=0.86 \mathrm{xx}$

$\mathrm{F}=$ Ruhm v. Enkhuizen: $\mathrm{y}=$ $-3.51+0.776 \mathrm{x}, \mathrm{r}=$ $0.98 \times x$

material, increased linearly $(\mathrm{y}=0.37+0.00244 \mathrm{x})$ as the A. brassicicola content increased (Fig. 5). The same trend was extremely clear in the case of the red cabbage variety - Amager $304-$, the seedling mortality curve increased sharply $\left(\mathrm{y}=0.921 \mathrm{e}^{0.04479 \mathrm{x}}\right)$ as the A. brassicicola content increased (Fig. 6).

The same values for the $A$. brassicicola content were obtained when the blotter method and agar method were used. Surface sterilisation of the seeds with $1 \% \mathrm{NaClO}$ decreased the fungus content, calculated as the average for 12 seed lots, from $61.5 \%$ to $5.5 \%$ (Table 5 ).

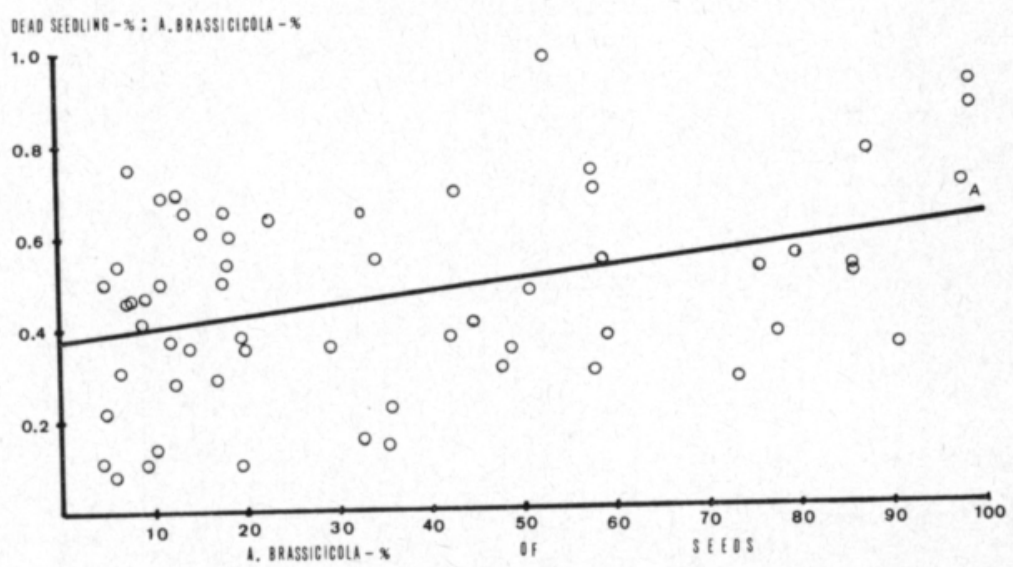

Fig. 5. The effect of Alternaria brassicicola content on the ratio between seedling mortality- $\%$ and $A$. brassicicola- $\%$ on a Jacobsen germinator.

A: $y=0.37+0.00244 x, r=0.37 x$ 


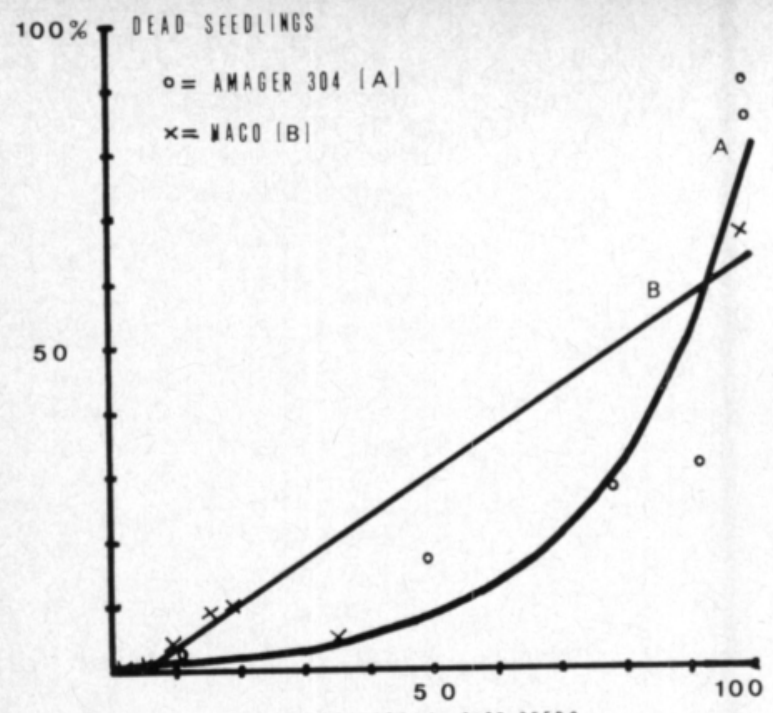

A. BRASSICICOLL-\% OF SEEOS
Fig. 6. The effect of Alternaria brassicicola on the seedling mortality of different varieties of red cabbage 10 days after sowing on a Jacobsen germinator.

$\mathrm{A}=$ Amager 304:

$\mathrm{y}=0.92 \mathrm{e}^{0.04479 \mathrm{x}}$,

$\mathrm{r}=0.96^{\mathbf{x x}}$

$\mathrm{B}=$ Haco: $\mathrm{y}=-3.56+0.681 \mathrm{x}$, $\mathrm{r}=0.96^{\mathrm{xx}}$

Table 5. Effect of surface sterilisation of seeds on the fungus contents of the seeds.

$\mathrm{A}=$ blotter method

$\mathrm{B}=$ agar method

$\mathrm{C}=$ agar method and surface sterilisation

\begin{tabular}{|c|c|c|c|c|c|c|c|}
\hline \multirow[b]{2}{*}{ Plant species } & \multirow[b]{2}{*}{ 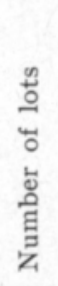 } & \multirow[b]{2}{*}{ 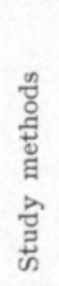 } & \multicolumn{5}{|c|}{ Mean $(\%)$ of infected lots } \\
\hline & & & 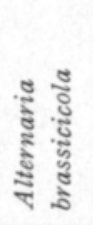 & 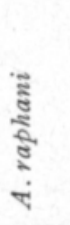 & 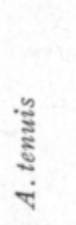 & 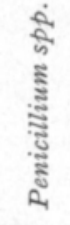 & 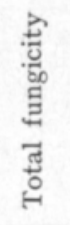 \\
\hline Cabbage .................... & 12 & $\begin{array}{l}\text { A } \\
\text { B } \\
\text { C }\end{array}$ & $\begin{array}{r}61.4 \\
61.5 \\
5.5\end{array}$ & - & - & $\begin{array}{r}27.6 \\
31.2 \\
4.7\end{array}$ & $\begin{array}{l}87.4 \\
92.1 \\
12.6\end{array}$ \\
\hline Swede ...................... & 3 & $\begin{array}{l}\text { A } \\
\text { B } \\
\text { C }\end{array}$ & $\begin{array}{l}- \\
- \\
-\end{array}$ & $\begin{array}{l}- \\
- \\
-\end{array}$ & $\begin{array}{r}11.5 \\
22.0 \\
5.0\end{array}$ & $\begin{array}{l}9.6 \\
7.0 \\
0\end{array}$ & $\begin{array}{r}31.5 \\
33.7 \\
2.0\end{array}$ \\
\hline Turnip .................... & 3 & $\begin{array}{l}\text { A } \\
\text { B } \\
\text { C }\end{array}$ & $\begin{array}{l}- \\
- \\
-\end{array}$ & $\begin{array}{l}- \\
- \\
-\end{array}$ & $\begin{array}{r}6.6 \\
14.5 \\
0\end{array}$ & $\begin{array}{r}12.3 \\
8.0 \\
1.3\end{array}$ & $\begin{array}{r}32.5 \\
22.7 \\
3.0\end{array}$ \\
\hline Rape and turnip rape & 7 & $\begin{array}{l}\text { A } \\
\text { B } \\
\text { C }\end{array}$ & $\begin{array}{l}- \\
- \\
-\end{array}$ & $\begin{array}{l}- \\
- \\
-\end{array}$ & $\begin{array}{r}10.0 \\
8.0 \\
3.5\end{array}$ & $\begin{array}{r}23.2 \\
13.3 \\
0.6\end{array}$ & $\begin{array}{r}44.5 \\
25.6 \\
3.6\end{array}$ \\
\hline $\begin{array}{l}\text { Radish and black } \\
\text { radish } \ldots \ldots \ldots \ldots \ldots \ldots \ldots \ldots \ldots\end{array}$ & 4 & $\begin{array}{l}\text { A } \\
\mathrm{B} \\
\mathrm{C}\end{array}$ & $\begin{array}{l}- \\
- \\
-\end{array}$ & $\begin{array}{l}5.2 \\
5.0 \\
9.6\end{array}$ & $\begin{array}{r}40.6 \\
71.7 \\
2.3\end{array}$ & $\begin{array}{r}11.5 \\
4.8 \\
1.8\end{array}$ & $\begin{array}{l}50.5 \\
68.8 \\
11.0\end{array}$ \\
\hline$\overline{\mathrm{x}}$ & & $\begin{array}{l}\text { A } \\
\text { B } \\
\text { C }\end{array}$ & $\begin{array}{r}61.4 \\
61.5 \\
5.5\end{array}$ & $\begin{array}{l}5.2 \\
5.0 \\
9.6\end{array}$ & $\begin{array}{r}17.2 \\
29.1 \\
2.7\end{array}$ & $\begin{array}{r}16.8 \\
12.9 \\
1.7\end{array}$ & $\begin{array}{r}49.3 \\
48.6 \\
6.4\end{array}$ \\
\hline
\end{tabular}


A. raphani (syn.: A. mathiolae Neergaard) is distributed throughout Europe, North-America, Egypt, India and Japan (Ellis 1971). The fungus is an economically significant and common seed-borne fungus on radish (Groves and Skolko 1944 b, Neergand 1945, Mclean 1947, ATKINson 1950). A. raphani causes damping-off and poorly-growing seedlings if the seeds are severely infected (NeErgaArd 1945, McLEan 1947). The fungus can infect the seeds right down to the embryo, thus preventing the seeds from germinating and weakening the effect of dressing (SAmRA 1956). Healthy radish seeds are brown in colour, but turn grey when they are heavily infected (NeERgaARd 1945).

On full-grown radish plants the fungus produces numerous leaf spots, from a few $\mathrm{mm}$ to about $1 \mathrm{~cm}$ in diameter, grayish to grayish black to brown, located chiefly on the lower leaves. Similar spots appear on the stems and siliques (NeErgaArd 1945, McLean 1947). It also occurs on Matthiola incana and other cruciferae (Ellis 1971).

The economical significance of the fungus is not proportional to its wide distribution. It is a weak parasite, but under particularly favourable conditions it may do some damage (NeERgaARd 1945).

The hyphae are hyaline to olivaceous brown, septate, $3-7 \mu$ wide. Clamydospores are formed abundantly in culture, sometime in chains, at first 1-celled, round, finally multi-cellular and irregular, brown, conidiophores often developing from them. The conidiophores are simple or occasionally branched, septate olivaceous brown up to $150 \mu$ long, $3-6 \mu$ thick, sometimes slightly swollen at the tip. The conidia (Fig. 11) form chains of $2-3$. They are smooth, straight or slightly curved, generally with a short beak, mid to dark golden brown or olivaceous brown, with 3-7 transverse septa and often a number of longitudinal or oblique septa, $60-120$ (75) $\mu$ long, $15-30$ (20) $\mu$ thick at their broadest part. The size of the conidium is the same as in the literature (Groves and SKolko 1944 b, NeERgaArd 1945).

A. raphani was found in 8 lots of radish seed and in one of black radish. The fungus contents varied from $0.5-8.0 \%$ (Table 1). On the Jacobsen germinator, the fungus was more common on dead than on living seedlings (Table 2).

In the pathogenicity tests, A. raphani was pathogenic to all the plants tested and damaged radish and turnip rape more severely than cauliflower, swede and turnip (Fig. 1).

\section{Botrytis cinerea Pers.}

The species is of worldwide distribution and almost ominivorous (Lindad 1907). This disease occurs frequently on most vegetables in storage and transit. It is conspicuous as a grey mould on cauliflower curds and the pathogen is one of the common ones on cabbage heads in storage (WALKER 1952). LinNasalmi (1952) has found that B. cinerea is a rare fungus on white cabbage and cauliflower seedlings suffering from damping-off. The fungus is an important secondary plant pathogen of cruciferous oil plants where it damages the siliqua. It is considered to be a primary pathogen of rape. On late rape, and turnip rape especially, it can cause damage during a damp autumn (Loof 1959).

$B$. cinerea is a rather rare seed-borne fungi of cruciferous plants. NEERGAARD (1951) has found it on kale and Shrmmer (1953) found Botrytis sp. on cauliflower. According to the study carried out by ANDERSEN (1970), B. cinerea occurred on swede, turnip, kale, white cabbage and other species of cabbage in sporadic cases, but it was more common on radish and rape seeds than on other cruciferous plants. 
B. cinerea was found on all plant species except for kohl-rabi, kale, Brussels sprouts, savoy cabbage and black radish. It was more common on red cabbage, swede and turnip rape than on other cruciferous species. The $B$. cinerea content of all the seed lots was in every case less than $4 \%$ (Table 1).

In the pathogenecity test, the fungus badly damaged the seedlings 10 days after sowing (Fig. 1 and 3). Cauliflower and radish were more susceptible than the other plant species. In seedling raising $B$. cinerea did not cause damping-off on either the sand or the peat substrate. The fungus had occasionally slightly damaged the cotyledons, and sometimes also the hypocotyls of kale, turnip, rape and turnip rape seedlings.

\section{Fusarium spp.}

Fusarium $s p p$. occurred on all the plant species studied apart from kale and broccoli. Between 19.0 and $66.7 \%$ of the white cabbage, cauliflower, red cabbage, Brussels sprouts, rape, radish and turnip rape lots were infected. 1-3 lots each of the other species were infected. The Fusarium contents of the infected lots were generally less than $5 \%$. In some of the white cabbage, Brussels sprouts, rape and turnip rape lots the fungus content was higher than $30 \%$ (Table 1). Only 11 of the 101 lots which had been on sale in 1974 or earlier were infected, but of the 171 lots which were on sale in 1975 and 1976, 63 were infected with Fusarium $s p p$.

F. avenacium (Corda ex Fr.) Sacc. was found in one lot each of white cabbage and red cabbage seeds. F. moniliforme Sheldon was in one lot each of white cabbage, Brussels sprouts and kohl-rabi seeds. F. oxysporum Schlecht. was found only in the lots on sale in 1975 and 1976.

Fusarium $s p p$. on the seed coats did not attack the developing seedlings during germination. Fusarium $s p p$. were significantly more common on ungerminated than on germinated seeds (Table 2). In the pathogenicity tests, F. moniliforme did not damage cauliflower (Fig. 3). F. oxysporum slightly damaged the test plants. Radish and rape were more severely damaged than cauliflower, swede and turnip (Fig. 1).

Fusarium spp. are not mentioned in the literature as important seed-borne fungi of cruciferous plants. Neergatard $(1948,1951)$ has reported the occurrence of $F$. avenaceum on cabbage. Fusarium spp, are not important damping-off fungi on cabbage (LinNasalmi 1952).

\section{Plenodomus lingam (Tode ex Fr.) Höhnel}

P. lingam (syn.: Phoma lingam (Tode ex Fr.) Desm., full synonyms are given by BoeremA and Kesteren (1964)) causes dry rot and damping-off in Brassica species. The perfect stage of the fungi is Leptosphaeria maculans (Desm.) Ces. \& de Not. (Boerema and Kasteren 1964, Sмith and Sutron 1964).

In many countries, especially in Australia (MACNish 1963), the USA (Henderson 1918) and New Zealand (LLOYD 1959), the fungus causes considerable damage to cabbage, swede and turnip. In many European countries this fungus reduces yields considerably (NIELSEN 1932, Bontea 1953, Schneider 1960, van Kampen 1964, Giessmann and Daebeler 1973).

The fungus can survive in fields for a number of years in cruciferous plants and plant remains (SNYder and BAKER 1950). According to the most recent study (Giessman and Daebeler 1973), P. lingam does not easily survive in plant remains. Some cruciferous weeds may be sources of this fungus (Bontea 1953, Giessmann and Daebeler 1973). Barbarea vulgaris, 
Capsell bursa-pastoris, Coronopus squamatus, Isatis tinctoria, Raphanu raphanistrum, Sinapis arvensis, Sisymbrium austriacum and Thlaspi arvense are such examples. However, seedborne infection is considered to be the most important source of this fungus (Pound et al. 1951, Giessman and Daebeler 1973). The critical fungus content in the seeds for the emergence of an epidemic on cabbage is $0.6 \%$. However, the prevailing weather conditions play a decisive role in whether or not such an outbreak will occur (GABriELson et al. 1977). In New Zealand, the spreading of this disease mainly takes place through ascospores produced in old plant stands (AlLEN and Sмrth 1961).

The fungus can attack all parts of the plant at any stage of development. Damping-off occurs at the seedling stage, and the disease manifests itself as dry rot during the growing season, continuing throughout the storage time (HENDERSON 1918).

In the seeds, the fungus grows deep down into the seed-coat or even as far as the embryo (JAcobsen and Williams 1971), where it can remain viable during the normal storage of seeds for as long as four years (NEERgaARD 1969). For this reason, hot water treatment or soaking in hot water-Germisan is usually recommended in the literature as a means of controlling this disease (Walker 1923, Cleyton 1925, Bontea 1953, van Kampen 1964, Williams 1967, NeERgaArd 1969). However, hot water, treatment is not at all effective if the seeds are badly infected (Williams 1967). MAUde et al. (1969) brought the fungus under control by soaking the seeds for $24 \mathrm{~h}$ in a $0.2 \%$ solution of thiram at $30^{\circ} \mathrm{C}$. On the other hand, JAcoBsen and WiLliams (1971) were not able to achieve complete control when they carried out a similar soaking with thiram, using seeds that were very badly infected $(21.5 \%)$. Soaking in $0.2 \%$ benomyl or thiabendazole solution for $24 \mathrm{~h}$ at $30^{\circ} \mathrm{C}$ gave complete control, however.

The mycelium of $P$. lingam is septate, branched, hyaline when young, becoming dark-walled with age. Pycnidia vary widely in size, usually from $120-360 \mu$. They are generally flask-shaped, usually dark coloured, sometimes with beaked or papillate ostioles (Fig. 8 a). The pycnospores are hyaline, nonseptate, $3-5 \mu \times 1-2.5 \mu$ (Fig. $8 \mathrm{~b}$ ). They are produced in abundance within the pycnidium, and on culture medium they emerge to form pinkish masses. The size of the fungus is the same as in the literatur (HENDERSON 1918, Smith and Sutton 1964, Giessmann and Daebeler 1973).

$P$. lingam was found in the seeds of white cabbage, cauliflower, red cabbage, swede and radish. $10 \%$ of the cabbage and $27 \%$ of the red cabbage seed lots were infected (Table 1). Two lots of swede seeds and one lot of radish were diseased. All the other plants were healthy. The fungus content of the seeds varied from $0.5-3 \%$, apart from two lots of red cabbage which had fungus contents of $6 \%$ ('Langendiger Sommer') and $14.2 \%$ ('Haco').

The fungus was more common on ungerminated than germinated seeds and more common on dead than on living seedlings ten days after seeding (Table 2). In the pathogenicity tests, P. lingam proved to be an extremely active causal agent of damping-off (Fig. 1 and 3). Cauliflower and turnip rape were more susceptible to damage caused by $P$. lingam than swede, turnip and radish. The fungus was the most serious causer of damping-off at the seedling stage of the seed-borne fungi of cruciferous plant studied.

\section{Rhizoctonia solani Kühn}

R. solani (Fig. 15) was found on one lot each of white cabbage, cauliflower, red cabbage and radish seeds. The fungus had spread from one seedling to another by the time of the second examination and killed all the seedlings. The fungus was already visible on the original seed when the seeds were examined for the first time. In the pathogenicity tests, $R$. solani isolated from cauliflower 
in 1972 killed all the cauliflower seedlings growing on sand within 5-6 days after inoculation, but $R$. solani isolated from cauliflower in 1974 was a weak pathogen (Fig. 2).

$R$. solani is rarely cited in the literature as a seed-brone fungus of crucifers: NEERGAARD (1958 a) found the fungus 68 times when studying 1045 seed lots. $R$. solani is carried as mycelia on the surface of the seed, as sclerotia or mycelia under the seed coat or even deep down inside the seed (BAKER 1947), but remains viable in cabbage seeds for less than ten months (NEERGAARD 1969).

\section{Ulocladium consortiale (Thum.) Simmons}

$U$. consortiale (Fig. 18) was a common seed-borne fungus on the seeds of cruciferous plants. It was found on all the plant species studied apart from kohl-rabi and black radish. About one quarter of the seed lots studied were infected. The fungus content of the seed lots varied from $0.5-15.5 \%$, usually being less than $5 \%$.

During germination on the Jacobsen germinator, $U$. consortiale did not damage any living seedlings but instead always remained on the seed coat. In the pathogenicity tests, the fungus had slighly damaged the cauliflower seedlings after two weeks (Fig. 3).

$U$. consortiale has been cited as a seed-borne fungus of cruciferous plants (GRoves and SKolko 1944 a, NeErgaArd 1945). The fungus is a saprophyte or weak parasite (NeERgaArd 1945, Linnansalmi 1952).

\section{3. Other fungi on cruciferous seeds}

Alternaria tenuis auct. (Fig. 12) was found on all the plant species studied apart from kohl-rabi and kale. This fungus is more rarely found on cabbage species than on other species. Less than $20 \%$ of the white cabbage seed lots were infected, the fungus content varying from $0.5-14 \%$ but in most cases less than $2 \%$. It was a common seed-borne fungus on swede, turnip, rape, turnip rape, radish and black radish. From one to two thirds of the seed lots of these plants were infected. The fungus content varied from $0.5-68 \%$ (Table 1).

A. tenuis was just as common on germinated as ungerminated seeds. The situation with dead and living seedlings was the same (Table 2). During germination the fungus usually remained on the seed coat and in no case, when it alone was present, did it kill the seedlings or damage the germlings. When the seedlings were grown on sand or on peat, A. tenuis was found in a number of instances on dead cotyledons, but the fungus never damaged the hypocotyl.

A slightly higher A. tenuis content was obtained with the agar method than with the blotter method. Surface sterilisation of the seeds removed the fungus from turnip, but the seeds of swede, rape, turnip rape, radish and black radish still retained $2-5 \%$ of the fungus (Table 5 ).

A. tenuis is a very common seed-borne fungus on a number of plants (Groves and SкоLко 1944 b, NeergaArd 1945, YLIMÄKI 1970, MäKelä 1972). It is usually a saprophyte (Ellis 1971), but in some plants it can cause slight damage under favourable conditions (NEERGAARD 1945). A.tenuis is a rather common fungus on the seeds of cabbage plants and radish, which, however, is a saprophyte or weak pathogen (NeErgaArd 1945, Mclean 1947, Morton 1964). 
Alternaria tenuissima (Fr.) Wiltsch. was found in five lots of white cabbage seed, one of cauliflower, one of swede and three of rape, the fungus content varying from $0.5-2.5 \%$ (Table 1). A. tenussima (Fig. 13) can be differentiated from $A$. tenuis by the beak in the conidium, which was usually swollen at the tip. On PDA medium, the fungus was morphologically similar to A. tenuis (cf. Neergaard 1945, Morton 1964). In the pathogenicity tests (Fig. 3), the fungus did not damage cauliflower at all (cf. Morton 1964).

Penicillium $s p p$. were found on all the plant species studied and in almost every seed lot. The fungus content of the infected seeds varied from 0.5 to $96 \%$. There were no significant differences between the Penicillium contents of the different plant species. There was no correlation between the fungus content and the germination percentage (Table 1). There were significantly less Penicillium $s p p$. on the Futura variety than on the other white cabbage varieties (Table 3 ).

Penicillium $s p p$. were more common on ungerminated seeds than on germinated ones. The fungi were as common on living as on dead seedlings ten days after sowing, apart from swede and turnip seedlings where the fungi were more common on dead than on living seedlings (Table 2).

During germination the fungi remained on top of the seed coat. The fungi had spread along the roots in only a few cases, causing the roots to turn red. During seedling raising the fungus did not occur on any dead seedlings. Penicillium $s p p$. were found only in dried cotyledons, together with other fungi.

Surface sterilisation of the seeds with $1 \% \mathrm{NaClO}$ removed Penicillium $s p p$. from the seeds. On the average, the same Penicillium contents were obtained when the health of the seeds was checked using the blotter method and the agar method (Table 5).

In addition, the following fungi were isolated from the seeds of the Cruciferous plants: Acremoniella atra (Corda) Sacc., Actinomucor spp., Arthrinium phaespermum (Corda) M. B. Ellis, Aspergillus spp., Chaetomium spp., Cladosporium cladosporioides (Fres.) Vries, Gonatobotrys simplex Gorda, Helminthosporium sativum Pammel, King \& Bakke, Ostragoderma stata Peziza ostragoderma Korf, Phoma herbarum Westd,. Mucor spp., Rhizopus nigrigans Ehrenberg, Sordaria sp., Stachybotrys atra Corda and Verticillium $s p p$. The fungus content was usually below $5 \%$. These fungi did not damage the seedlings when they occurred alone.

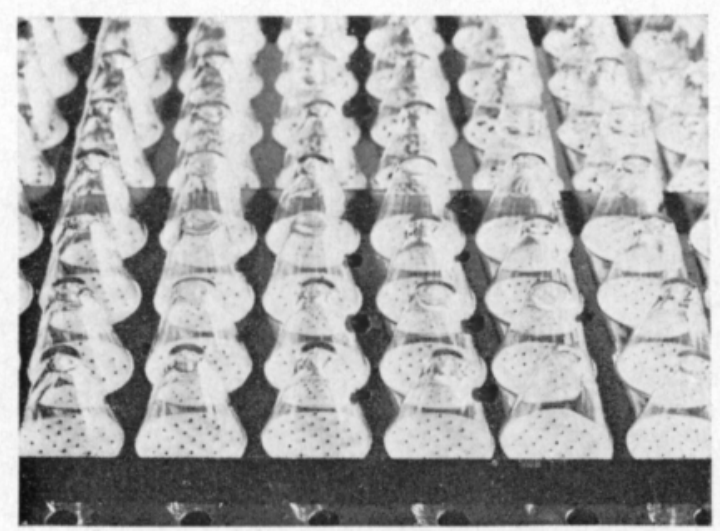

Fig. 7. Jacobsen germinator. 


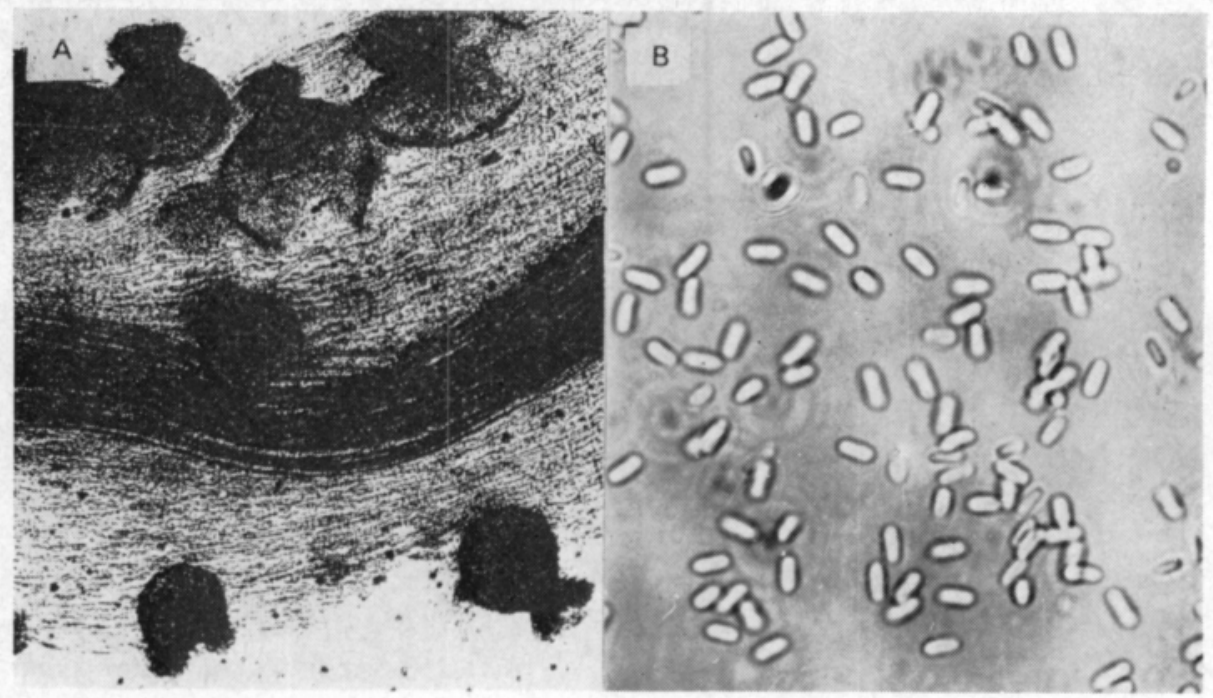

Fig. 8. Plenodomus lingam, a: pycnidia on dead seedling, x 100, b: codia, x 1000 .

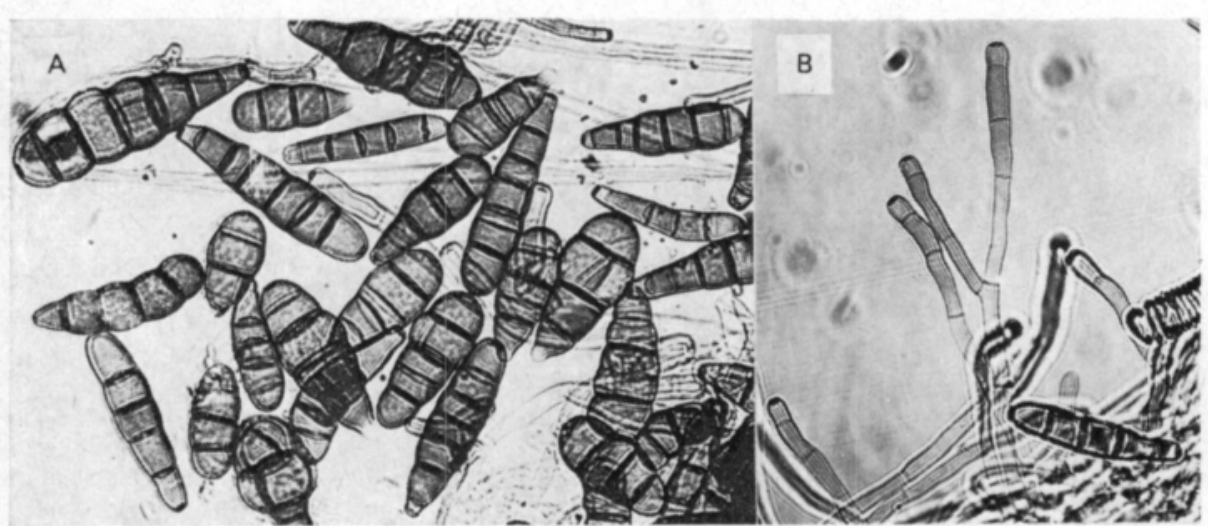

Fig. 9. Alternaria brassicicola, a: conidia x 500, b: conidiophores x 500 .

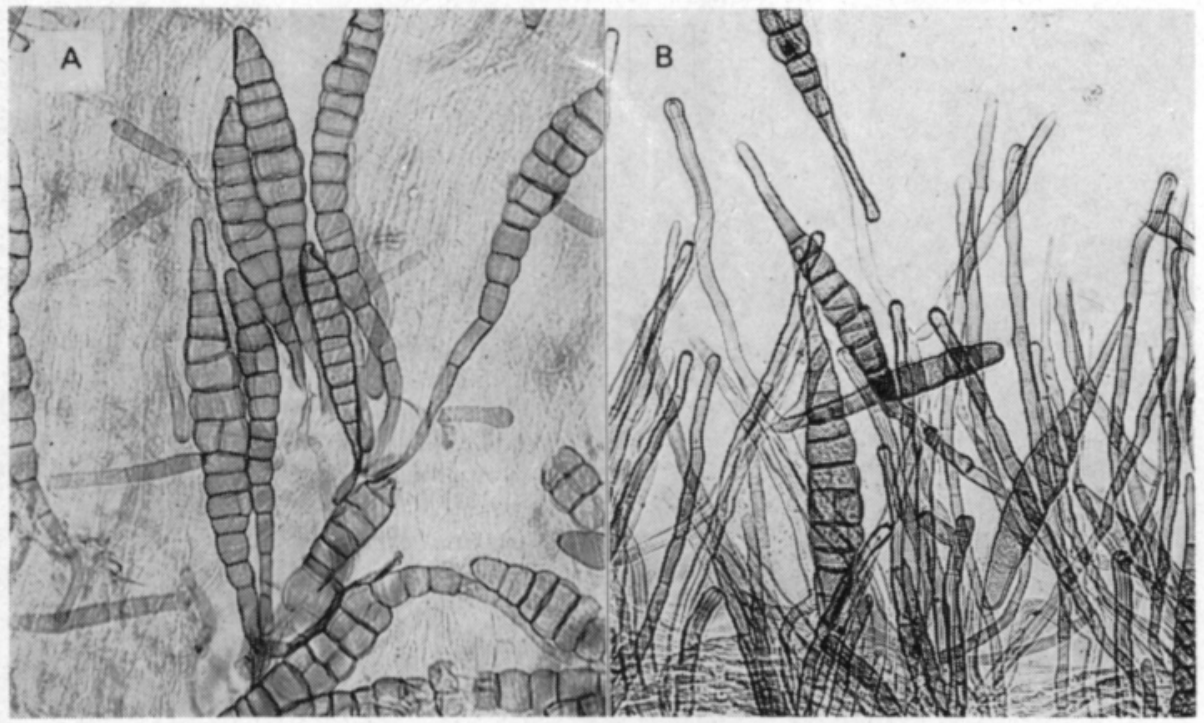

Fig. 10. Alternaria brassicae, a: conidia $\times 250$, b: conidiophores $\times 250$. 


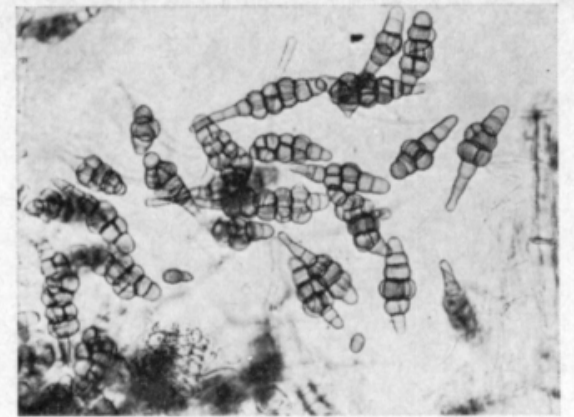

Fig. 11. Alterraria raphani, x 250 .

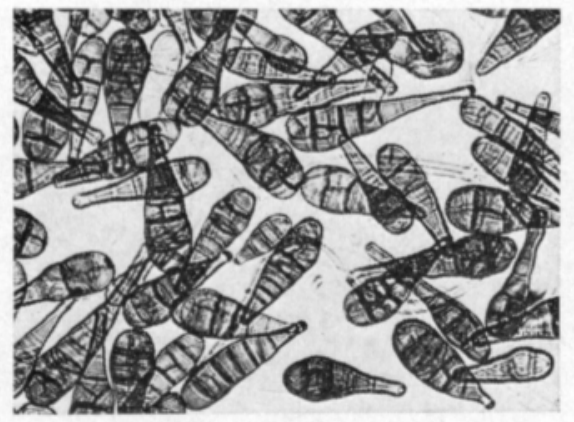

Fig. 13. Alternaria tenuissima, x 500 .

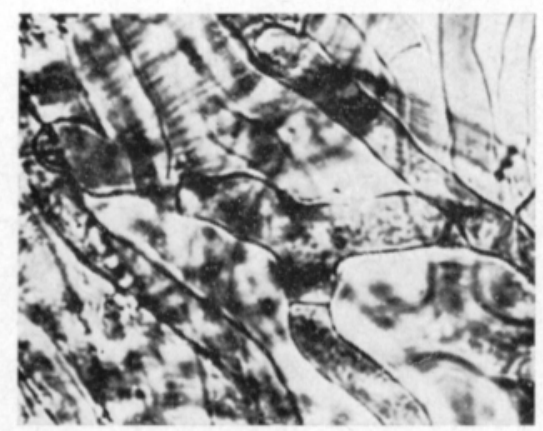

Fig. 15. Rhizoctonia solani, x 500 .

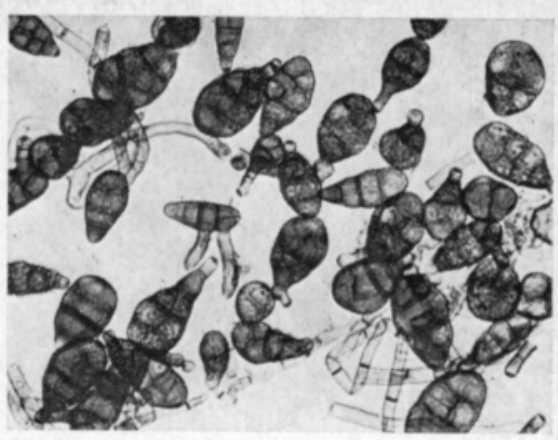

Fig. 12. Alternaria tenuis, x 500 .

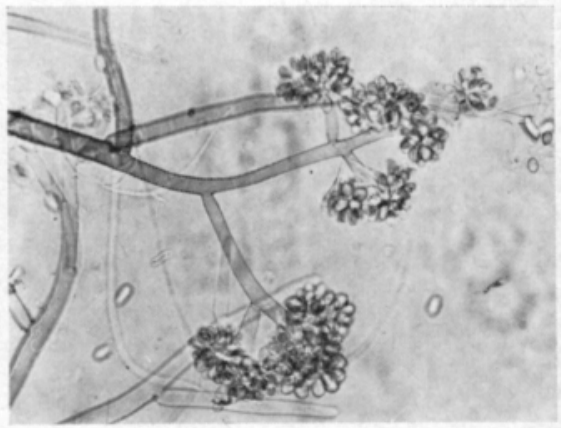

Fig. 14. Botrytis cinerea, x 250.

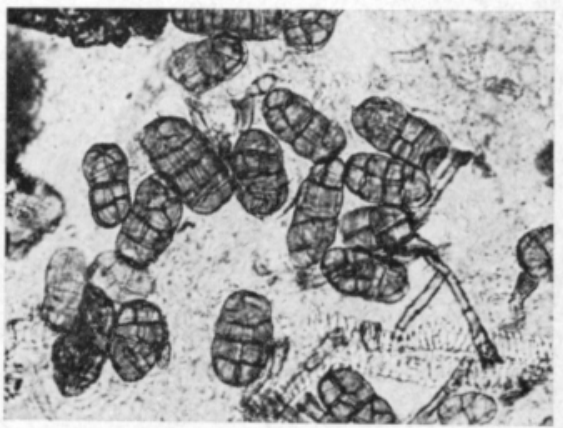

Fig. 16. Stemphylium botryosum, x 250 . 


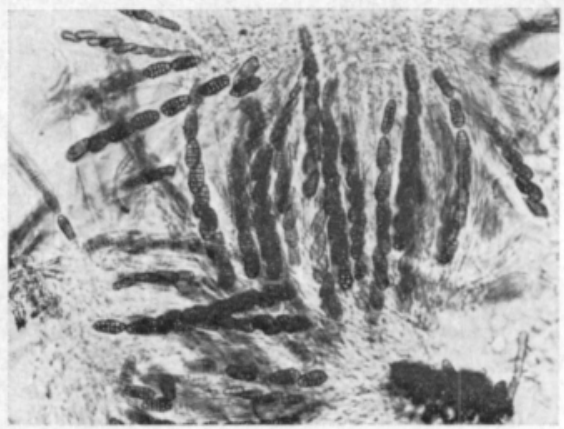

Fig. 17. Pleospora herbarum, x 250.

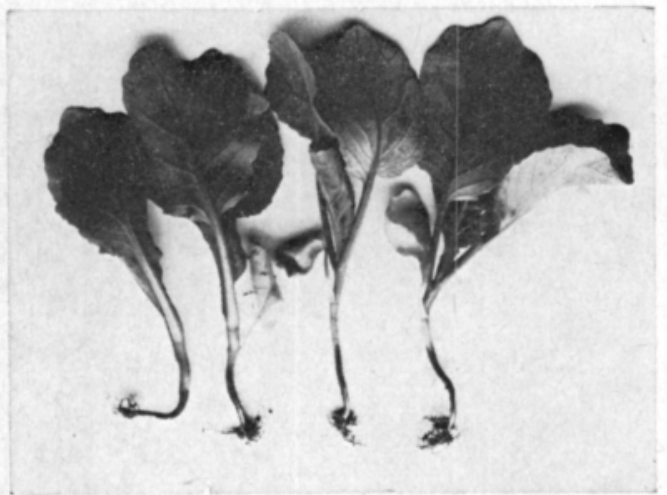

Fig. 19. Damping-off on cabbage seedlings caused by Plenodomus lingam.

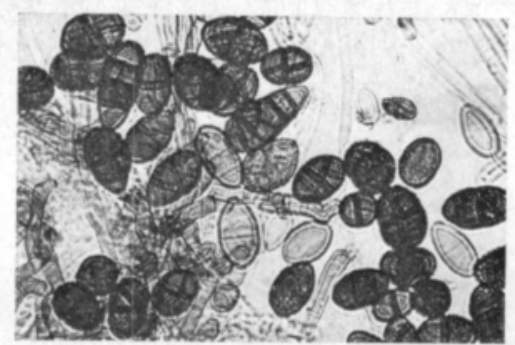

Fig. 18. Ulocladium consortiale, x 500 .

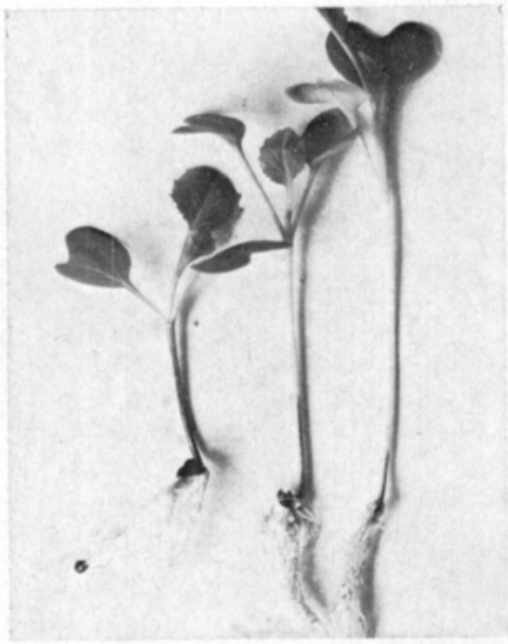

Fig. 20. Damage to cabbage seedlings caused by Alternaria brassicicola

\section{Importance of seed-borne fungi of crucifers in seedling raising}

\subsection{Effect of seed-borne fungi on seedling emergence and seedling growth}

Of the seed-borne fungi of crucifers, only Alternaria brassicicola and Plenodomus lingam were serious causal agents of damping-off or damaged seedlings. The amounts of other pathogenic fungi in the infected seeds were naturally so low, or the fungi were such weak pathogens, that they did not cause dampingoff to any marked degree, damage seedlings or weaken growth. Of the other fungi, only Alternaria raphani on radish seeds caused the death of or damage to a few individual seedlings. The type of damage caused by different fungi are presented in connection with the description of the individual fungi.

\subsubsection{Damping-off}

Alternaria brassicicola caused a significant amount of damping-off and seedling damage (Fig. 20) in cabbage seeds where they occurred in considerable 
amounts (Fig. 21). The number of seedlings suffering from damping-off and damaged on sterilised sand substrate increased with increasing A. brassicicola-\% $(y=-5.81+0.85 x)$. On the basis of this material, if about $20 \%$ of the seeds are infected then about $10 \%$ of a seedling stand would be destroyed. Seedling damage was much smaller on fresh peat substrate than on the sterile substrate. Damage increased with increasing $A$. brassicicola- $\%$ according to the curve, $y=0.019 \mathrm{e}^{0.0865 x}$. The $10 \%$ damage threshhold was not reached until the $A$. brassicicola content was over $70 \%$.

A. brassicicola did not cause damping-off before emergence (Fig. 22) to any great extent on the peat substrate, but on sterile sand it gradually increased, according to the line, $\mathrm{y}=5.06+0.12 \mathrm{x}$, as the fungus content of the seeds increased.

Plenodomus lingam was a serious damping-off fungi which caused dampingoff, on sand substrate, from naturally infected seeds as much as there were seeds infected by the fungus (Table 13). On the peat substrate, the fungus caused a certain amount of damping-off with artificially infected seeds (Fig. 23).

Fig. 21. The effect of seed-borne Alternaria brassicicola on the number of dead and damaged cabbage seedlings on the sand (A) and peat (B) substrates.

$A: y=-5.91+0.85 x, r=0.79 \times x$ $B: y=0.019 e^{0.0865 x}, r=0.68 \times x$

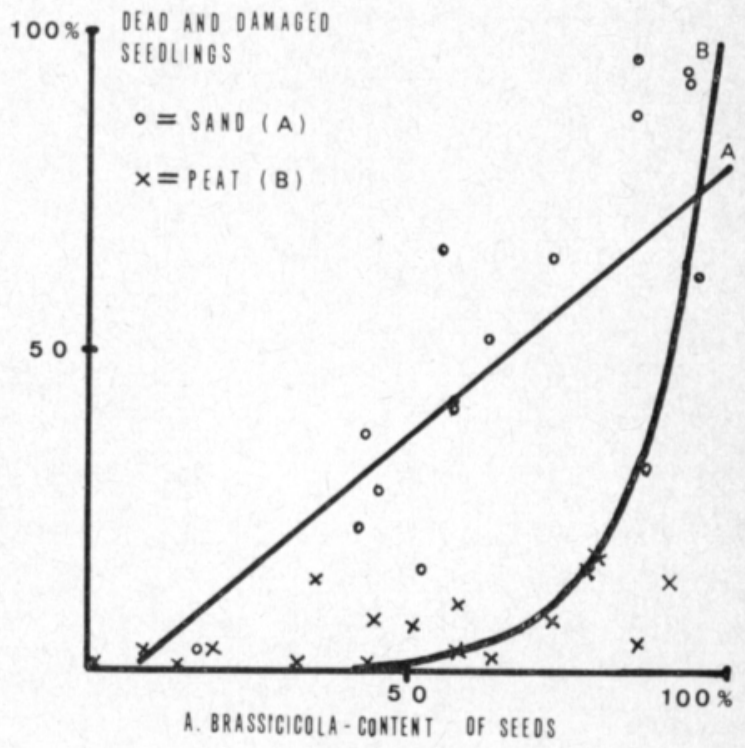

\subsubsection{Seedling growth}

In addition to damping-off, $A$. brassicicola also caused a reduction in the growth of the seedlings without apparently damaging the seedlings. While the relative weight of healthy seedlings grown from 14 seriously infected seed lots (A. brassicicola contents of $39-86 \%$ ) was 100 , the weight of seedlings grown from similar surface-sterilised seeds, the fungus contents of which were all under $5 \%$, was $\mathbf{1 1 3 . 5}$. The difference was statistically significant at the $0.1 \%$ risk level. No corresponding weight reductions were observed between healthy seed lots or lots infected with other fungi (Table 6). 

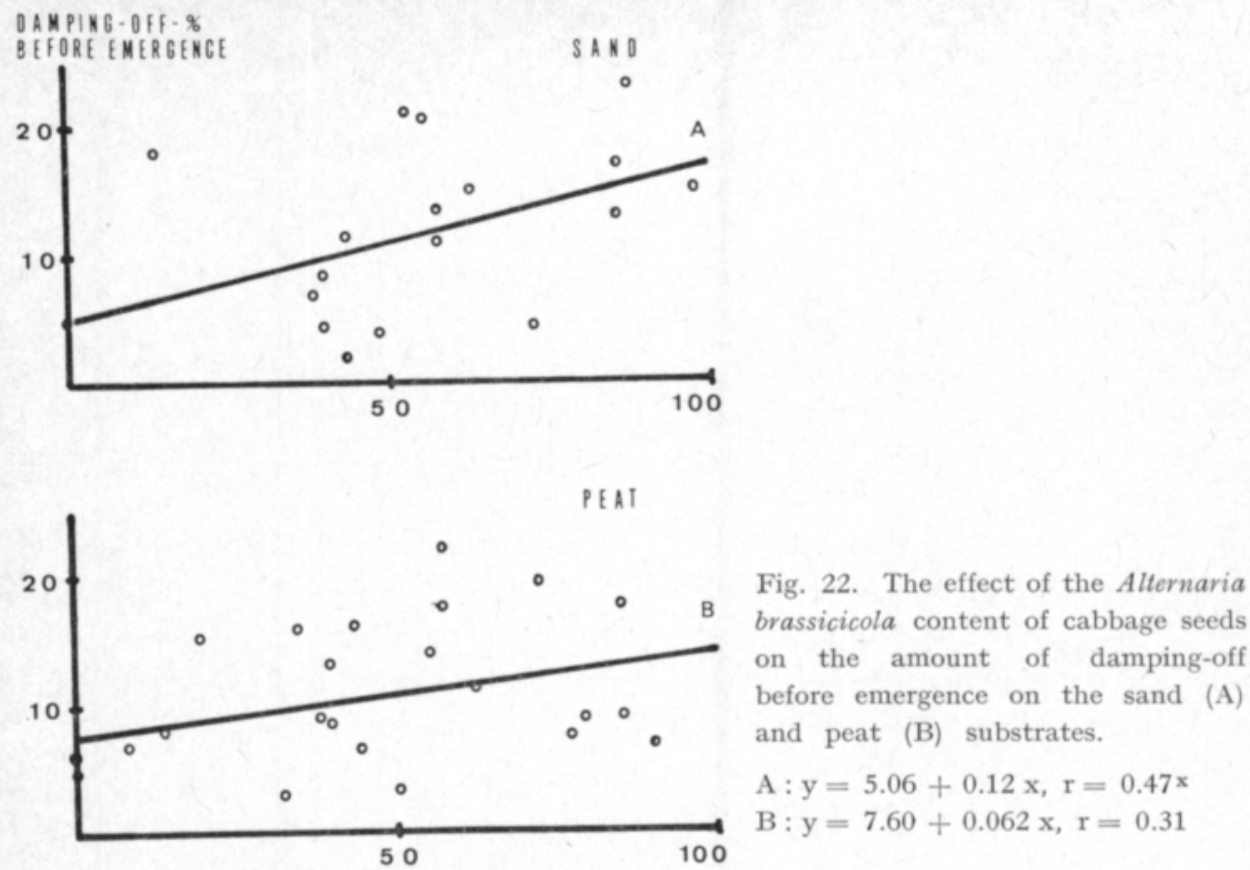

Table 6. Effect of seed-borne Alternaria brassicicola on the relative dry-weight of undamaged seedlings grown for 4 weeks on the peat substrate.

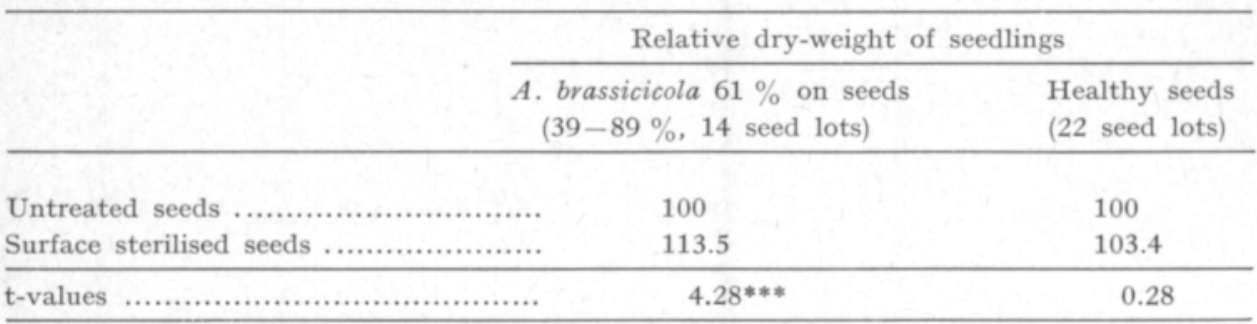

\subsubsection{Importance of contamination in peat substrate}

Inoculation of the peat substrate before sowing with the most important seed-borne fungi of crucifers did not decrease the emergence of white cabbage, cauliflower, red cabbage and Brussels sprouts (Table 7). A. brassicicola slightly damaged white cabbage and cauliflower. P. lingam killed less than $2 \%$ of the seedlings of all the plant species tested. A. brassicae and Botrytis cinerea did not damage the seedlings at all.

However, the fungi slowed down the growth of the seedlings on the peat substrate (Table 8). The dry weight of seedlings grown on substrate infected with $A$. brassicicola was $0.07 \mathrm{~g}$ less than that of the control seedlings and $0.04 \mathrm{~g}$ less when infected with other fungi $\left(\mathrm{LSD}_{\mathrm{t} 0.05}=0.03 \mathrm{~g}\right)$. 
Table 7. Effect of inoculating the peat substrate with different fungi one week before sowing on the emergence of different cabbage species. Dead and damaged seedlings, expressed as a percentage of emerged seedlings, are given in brackets.

\begin{tabular}{|c|c|c|c|c|c|}
\hline \multirow{2}{*}{ Inoculate } & \multicolumn{3}{|c|}{$\begin{array}{c}\text { Emergence - \% } \\
\text { (dead and damaged \%) }\end{array}$} & \multirow[b]{2}{*}{$\begin{array}{l}\text { Brussels } \\
\text { sprouts }\end{array}$} & \multirow[b]{2}{*}{$\overline{\mathbf{x}}$} \\
\hline & $\begin{array}{l}\text { White } \\
\text { cabbage }\end{array}$ & $\begin{array}{l}\text { Cauli- } \\
\text { flower }\end{array}$ & $\begin{array}{c}\text { Red } \\
\text { cabbage }\end{array}$ & & \\
\hline Control ........................... & $\begin{array}{l}80 \\
(0)\end{array}$ & $\begin{array}{l}88 \\
(0)\end{array}$ & $\begin{array}{l}91 \\
(0)\end{array}$ & $\begin{array}{l}80 \\
(0)\end{array}$ & $\begin{array}{l}85 \\
(0)\end{array}$ \\
\hline Alternaria brassicicola ....... & $\begin{array}{l}84 \\
(0.6)\end{array}$ & $\begin{array}{l}85 \\
(1.5)\end{array}$ & $\begin{array}{l}90 \\
(0)\end{array}$ & $\begin{array}{l}76 \\
(0)\end{array}$ & $\begin{array}{l}84 \\
(0.5\end{array}$ \\
\hline A. brassicae ..................... & $\begin{array}{l}85 \\
(0)\end{array}$ & $\begin{array}{l}88 \\
(0)\end{array}$ & $\begin{array}{l}89 \\
(0)\end{array}$ & $\begin{array}{l}78 \\
(0)\end{array}$ & $\begin{array}{l}85 \\
(0)\end{array}$ \\
\hline Botrytis cinerea ................. & $\begin{array}{l}86 \\
(0)\end{array}$ & $\begin{array}{l}89 \\
(0)\end{array}$ & $\begin{array}{l}89 \\
(0)\end{array}$ & $\begin{array}{l}67 \\
(0)\end{array}$ & $\begin{array}{l}84 \\
(0)\end{array}$ \\
\hline Plenodomus lingam .......... & $\begin{array}{l}76 \\
(1.3)\end{array}$ & $\begin{array}{l}86 \\
(0.3)\end{array}$ & $\begin{array}{l}90 \\
(0.8)\end{array}$ & $\begin{array}{l}80 \\
(1.9)\end{array}$ & $\begin{array}{l}83 \\
(1.1\end{array}$ \\
\hline 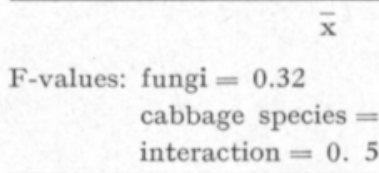 & 82 & 87 & 90 & 76 & 84 \\
\hline
\end{tabular}

Table 8. Effect of inoculating the peat substrate with different fungi one week before sowing on the dry-weight of the seedlings of different cabbage species.

\begin{tabular}{|c|c|c|c|c|c|}
\hline \multirow[b]{2}{*}{ Inoculate } & \multicolumn{3}{|c|}{ Dry-weight $\mathrm{g} /$ seedling } & \multirow[b]{2}{*}{$\begin{array}{c}\text { Brussels } \\
\text { sprouts }\end{array}$} & \multirow[b]{2}{*}{$\overline{\mathbf{x}}$} \\
\hline & $\begin{array}{l}\text { White } \\
\text { cabbage }\end{array}$ & $\begin{array}{l}\text { Cauli- } \\
\text { flower }\end{array}$ & $\begin{array}{c}\text { Red } \\
\text { cabbage }\end{array}$ & & \\
\hline Control ........................... & 0.43 & 0.22 & 0.39 & 0.26 & 0.33 \\
\hline Alternaria brassicicola ....... & 0.30 & 0.19 & 0.35 & $0 \cdot 21$ & 0.26 \\
\hline A. brassicae .................... & 0.35 & 0.19 & 0.38 & 0.23 & 0.26 \\
\hline Botrytis cinerea ................ & 0.31 & 0.23 & 0.40 & 0.23 & 0.29 \\
\hline Plenodomus lingam .......... & 0.39 & 0.21 & 0.38 ， & 0.22 & 0.29 \\
\hline $\bar{x}$ & 0.35 & 0.21 & 0.38 & 0.23 & 0.29 \\
\hline \multicolumn{5}{|c|}{$\begin{array}{c}\text { F-values: } \text { fungi }=1.70^{*}, \mathrm{LSD}_{\text {to. } .05}=0.03 \mathrm{~g} \\
\text { plant species }=89.4^{* * *}\end{array}$} & \\
\hline
\end{tabular}

\section{2. Effect of different growth substrates on Alternaria brassicicola and Plenodomus lingam}

\section{2.1. Seedling emergence and damping-off}

As many cauliflower seeds infected with A. brassicicola and Plenodomus lingam emerged on fresh and steam-sterilised peat as healthy seeds. However, less infected seeds emerged on steam-sterilised soil (Table 9).

The emergence of both healthy and infected seeds was not as good in unsterilised tilled soil as in other types of substrate. 
Fresh peat almost completely prevented damping-off caused by $A$. brassicicola and significantly decreased the amount of damping-off caused by P. lingam in comparison to steam-sterilised substrates (Table 10). There was less dampingoff caused by $A$. brassicicola on the steam-sterilised peat substrate than on the steam-sterilised soil substrate.

Table 9. Effect of different types of substrate on the emergence of healthy 'Erfurter 291' cauliflower seeds, infected with Alternaria brassicicola or Plenodomus lingam.

\begin{tabular}{|c|c|c|c|c|c|}
\hline & \multicolumn{4}{|c|}{ Emergence-\% } & \multirow[b]{2}{*}{$\overline{\mathbf{x}}$} \\
\hline & $\begin{array}{l}\text { Fresh } \\
\text { peat }\end{array}$ & $\begin{array}{c}\text { Steam- } \\
\text { treated } \\
\text { peat }\end{array}$ & Mull & $\begin{array}{c}\text { Steam- } \\
\text { treated } \\
\text { mull }\end{array}$ & \\
\hline 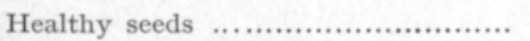 & 89 & 85 & 58 & 88 & 80 \\
\hline A. brassicicola-inoculated seeds ......... & 85 & 77 & 44 & 50 & 64 \\
\hline$P$. lingam inoculated seeds .............. & 79 & 85 & 50 & 63 & 69 \\
\hline$\overline{\mathbf{x}}$ & 84 & 82 & 51 & 67 & 71 \\
\hline $\begin{array}{l}\text { F-values: fungi }=16.7 * * \text {, substrates }= \\
\text { LSD }_{\text {t0.05 }}: \text { fungi }=7.5 \% \text {, substrates }=\end{array}$ & $\begin{array}{l}42.2 * * *, \\
7.0 \%, \mathrm{~s}\end{array}$ & $\begin{array}{l}\text { teraction } \\
\text { strates, w }\end{array}$ & $\begin{array}{l}23.3^{*} \\
\text { en fun }\end{array}$ & same & \\
\hline
\end{tabular}

Table 10. Effect of different types of substrate on the degree of damping-off on 'Erfurter 291' cauliflower when seeds are healthy, infected with Alternaria brassisicola or Plenodomus lingam.

\begin{tabular}{lcc}
\multicolumn{3}{c}{ Damping-off- $\%$} \\
\hline $\begin{array}{l}\text { Fresh } \\
\text { peat }\end{array}$ & $\begin{array}{l}\text { Steam- } \\
\text { treated }\end{array}$ & $\begin{array}{c}\text { Steam- } \\
\text { treated } \\
\text { mull }\end{array}$ \\
\hline
\end{tabular}

\begin{tabular}{lrrrrrr} 
Healthy seeds ......................... & 0.0 & 1.1 & 1.6 & 0.0 & 0.7 \\
A. brassicicola inoculated seeds $\ldots \ldots \ldots$. & 1.4 & 56.9 & 10.2 & 98.3 & 41.7 \\
$P$. lingam inoculated seeds …......... & 31.8 & 97.4 & 24.5 & 86.3 & 60.0 \\
\hline$\overline{\mathrm{x}}$ & 11.1 & 51.8 & 12.1 & 61.5 & 34.1
\end{tabular}

F-values: fungi $=161.3^{* * *}$, substrates $=80.3^{* * *}$, interaction $=25.5^{* *}$

$\mathrm{LSD}_{\mathrm{t} 0.05}$ : fungi $=8.3 \%$, substrates $=8.5 \%$, substrates, when fungus is same $=14.8 \%$

\subsubsection{Spreading of the fungi}

A. brassicicola did not spread on the peat substrate from infected seeds to healthy seeds even when a sowing spacing of $2 \mathrm{~cm}$ was used. On the steamsterilised soil substrate, however, $10 \%$ of the seedlings were infected even with a spacing of $8 \mathrm{~cm}$ (Table 11). In fresh peat, $P$. lingam infected $3.7 \%$ of the seedlings at a spacing of 2 and $4 \mathrm{~cm}$. In steam-sterilised soil, the fungus spread to almost half of the seedlings when a spacing of $2 \mathrm{~cm}$ was used, and $13 \%$ were infected with a spacing of $8 \mathrm{~cm}$. 
$P$. lingam caused almost complete destruction with infected seeds on the steam-sterilised mull substrate about 2.5 weeks after sowing, and with $A$. brassicicola 4.5 weeks after sowing (Fig. 23). There was only a small amount of $A$. brassicicola damping-off on fresh peat substrate and it did not increase during the time when the seedlings were grown. However, the damage caused by $P$. lingam increased uniformly and reached a level of about $30 \%$ by the end of the growing period.

Table 11. Infection of seedlings grown from healthy 'Erfurter 291' cauliflower seeds by Alternaria brassicicola and Plenodomus lingam from infected seeds sown at different spacings on peat and steam-sterilised mull substrate.

Distance between two rows

Infection- $\%$ of emerged seedlings

\begin{tabular}{|c|c|c|c|c|c|}
\hline 政 & & A. brassicicola & P. lingam & A. brassicicola & P. lingam \\
\hline $2 \mathrm{~cm}$ & 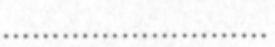 & 0 & 3.7 & 36.0 & 41.6 \\
\hline $4 \mathrm{~cm}$ & 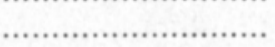 & 0 & 3.7 & 10.0 & 26.7 \\
\hline $8 \mathrm{~cm}$. & 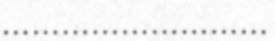 & 0 & 0 & 10.0 & 13.3 \\
\hline
\end{tabular}

Fig. 23. The effect of peat and steamsterilised mull substrates on the mortality rate of seedlings grown at different spacing densities from 'Erfurter 291' cauliflower seeds infected with Alternaria brassicicola and Plenodomus lingam.

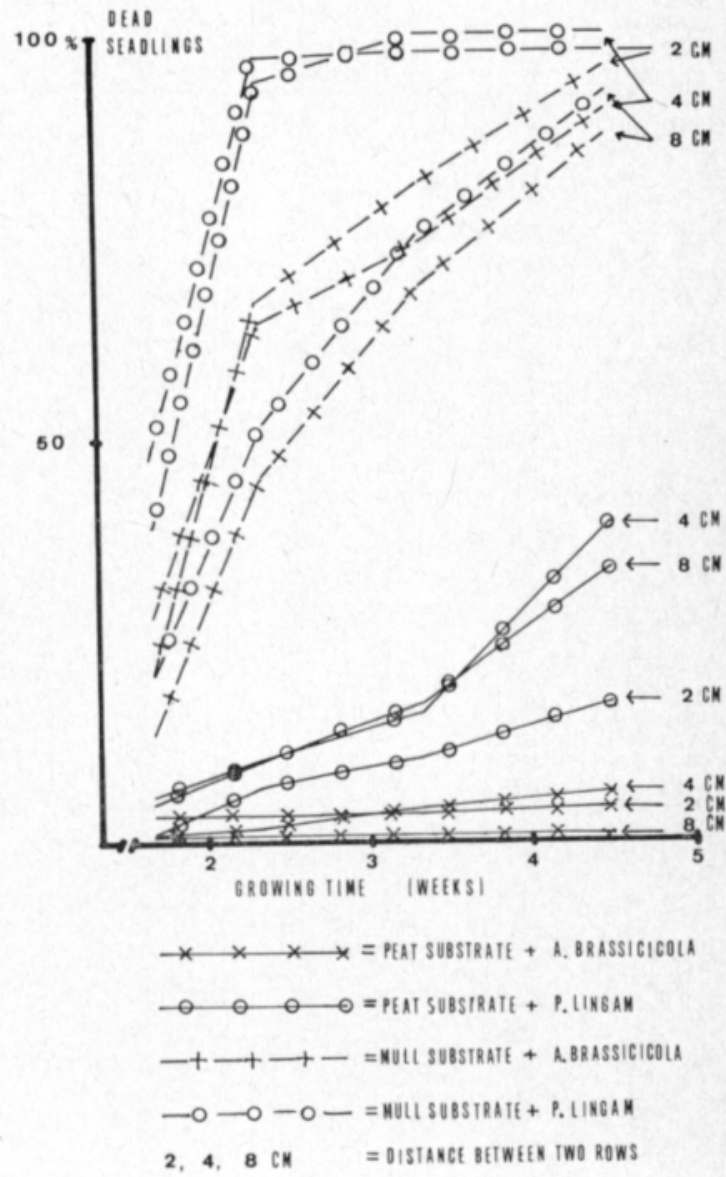




\subsection{Effect of temperature on Alternaria brassicicola and Plenodomus lingam in seedling raising}

\subsubsection{Alternaria brassicicola}

A. brassicicola caused more damping-off at a high temperature on sterile sand substrate than at a low temperature. According to this study, at low temperatures seeds which are $100 \%$ infected cause damage of less than $10 \%$, while at high temperatures the amount of damage is about $50 \%$ (Fig. 24).

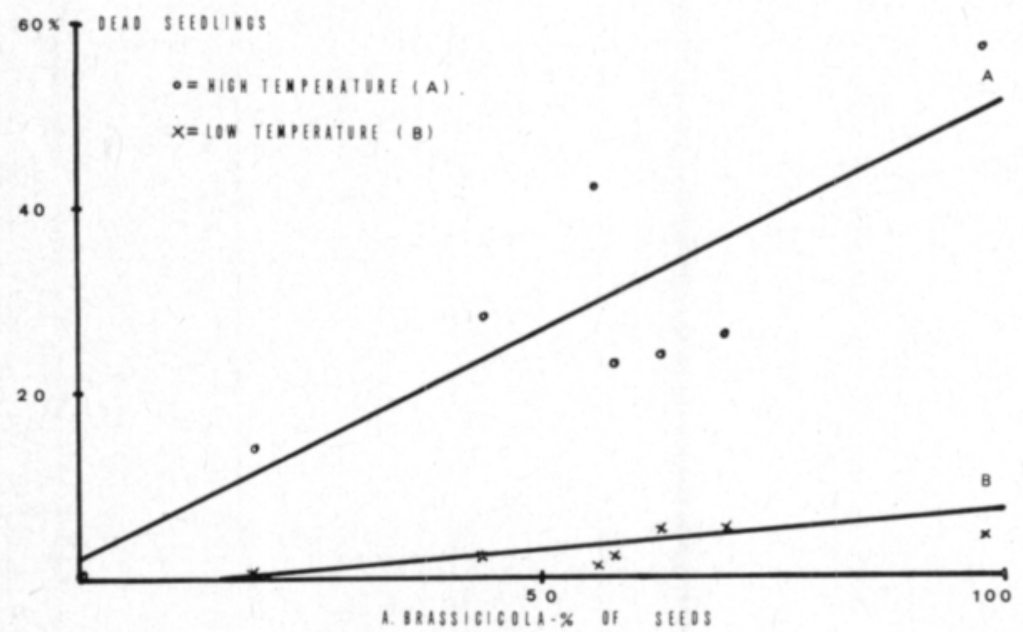

Fig. 24. The effect of different temperature regimes (high, $18^{\circ} \mathrm{C}$ at night and $15^{\circ} \mathrm{C}$ during the day, and low, $8^{\circ} \mathrm{C}$ at night and $15^{\circ} \mathrm{C}$ during the day) on the amount of damping-off caused by seed-borne Alternaria brassisicola on the sand substrate.
A : $y=1.63+0.49 x, r=0.86^{x x}$
$B: y=-1.65+0.087 x, r=0.83 x x$

On the peat substrate, A. brassicicola did not cause a significant amount of damping-off at either temperature. On the other hand, at a high temperature severely infected seeds significantly decreased the growth of the seedlings without causing any visible damage in comparison to surface-sterilised seeds which were almost completely healthy (Table 12).

\subsubsection{Plenodomus lingam}

The temperature at which the seedlings were grown had no effect on the seedling emergence and damping-off when seeds severely infected with $P$. lingam ( $P$. lingam content of $13.4 \%$ ) were used (Table 13). 
Table 12. Effect of seed-borne Alternaria brassicicola on the dry-weight of 'Futura' white cabbage, 'Erfurter 291' cauliflower, 'Amager 304' red cabbage seedlings grown at different temperatures on peat substrate. The number of dead and damaged seedlings are given as a percentage of emerged seedlings in brackets. $\mathrm{I}=$ untreated seed, II $=$ surface-sterilised seed.

\begin{tabular}{lcccccccc}
\hline & \multicolumn{2}{c}{ White cabbage } & \multicolumn{2}{c}{ Cauliflower } & \multicolumn{2}{c}{ Red cabbage } & \multicolumn{2}{c}{ Mean } \\
\cline { 2 - 9 } $\begin{array}{l}\text { Seed treatment } \\
\begin{array}{l}\text { A. brassicicola- } \% \\
\text { on seeds }\end{array}\end{array}$ & I & II & I & II & I & II & I & II \\
\hline
\end{tabular}

Night and day

temperature

$18^{\circ} \mathrm{C}$ and $25^{\circ} \mathrm{C}$

1.55

(4.5)

1.85

(0)

$8^{\circ} \mathrm{C}$ and $15^{\circ} \mathrm{C}$

1.70

1.70

1.88

(0)

$\overline{\mathrm{x}} \quad 1.63$

(2.3)

(0)

Dry-weight $\mathrm{g} / 20$ seedlings

1.05

(2.3)

0.83

0.83

(1.9)

0.94

(2.1)

F-values: seed treatment: high temperature $=49.6 * * *$

low temperature $=7.65$

\subsection{8}

(0)

1.23

(1.8)

1.68

1.28

1.57

1.05

1.10

(0.6)

(2.9)

(0.2)

(0)

$1.12 \quad 1.17$

(2.3)

(0)

(2.1)

1.13

1.21

1.35

(1.4) (0)

1.23

1.46

1.41

(2.2)

(0.1)

Table 13. Effect of growing temperature on the degree of damping-off caused by seed-borne Plenodomus lingam to 'Haco' red cabbage seedlings on the sand substrate. The fungus content of the seeds was $13.4 \%$.

\begin{tabular}{lcccc}
\hline & \multicolumn{4}{c}{ Growing temperature } \\
& $\begin{array}{c}\text { nigh } 8^{\circ} \mathrm{C} \\
\text { day } 15^{\circ} \mathrm{C}\end{array}$ & $\begin{array}{c}\text { nigh } 18^{\circ} \mathrm{C} \\
\text { day } 25^{\circ} \mathrm{C}\end{array}$ & F-values \\
\hline Emergence- $\% \ldots \ldots$. & 73.5 & 75.3 & 0.17 \\
Damping-off- $\% \ldots \ldots$ & 15.3 & 15.2 & 0.07 \\
\hline
\end{tabular}

\section{4. Control of Alternaria brassicicola}

Surface sterilisation of the seeds as is generally used in laboratory experiments and normal dressing with thiram affected the A. brassicicola content of the seeds as follows:

\begin{tabular}{|c|c|c|c|}
\hline Treatment & $\begin{array}{l}\text { Cabbage } \\
\text { 'Futura Ff' }\end{array}$ & $\begin{array}{l}\text { Cauliflower } \\
\text { 'Erfurter 291' }\end{array}$ & $\begin{array}{l}\text { Red cabbage } \\
\text { 'Amager } 304 \text { ' }\end{array}$ \\
\hline 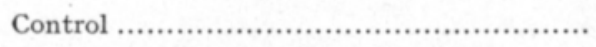 & $81 \%$ & $51 \%$ & $78 \%$ \\
\hline Surface sterilisation with $\mathrm{NaClO}$.............. & $6 \%$ & $6 \%$ & $3 \%$ \\
\hline Thiram dressing ..................................... & $2 \%$ & $3 \%$ & $2 \%$ \\
\hline
\end{tabular}

In the seedling raising experiments, surface sterilisation and dressing with thiram completely eliminated damping-off caused by $A$. brassicicola. Similarly, spraying the substrate with a thiram preparation before or after emergence eliminated or significantly decreased damping-off (Table 14). 
Spraying the substrate with thiram before emergence reduced the growth of the seedlings. When seed-borne A. brassicicola was controlled by means of dressing or surface sterilisation of the seeds, the seedlings grew more strongly than the untreated seedlings or those sprayed with thiram after emergence (Table 15).

Table 14. Effect of different seed and substrate treatments on the damage caused to seedlings by seed-borne Alternaria brassicicola on the peat substrate.
$A=$ control
$\mathrm{B}=$ surface-sterilisation of the seeds
$\mathrm{C}=$ thiram dressing
$\mathrm{D}=$ spraying the substrate with thiram before seedling emergence
$\mathrm{E}=$ spraying the substrate with thiram after seedling emergence

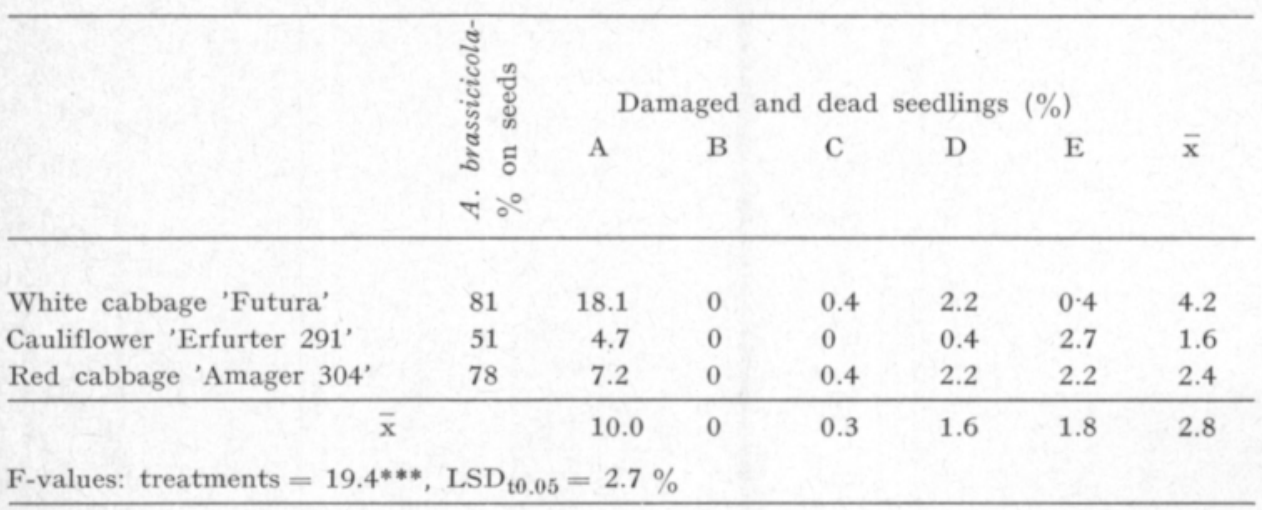

Table 15. Effect of different seed and substrate treatments on the dry-weight of seedlings grown on the peat substrate from seeds infected with Alternaria brassicicola.
$A=$ control
$\mathrm{B}=$ surface-sterilisation of the seeds
$\mathrm{C}=$ thiram dressing
$\mathrm{D}=$ spraying the substrate with thiram before seedling emergence
$\mathrm{E}=$ spraying the substrate with thiram after seedling emergence.

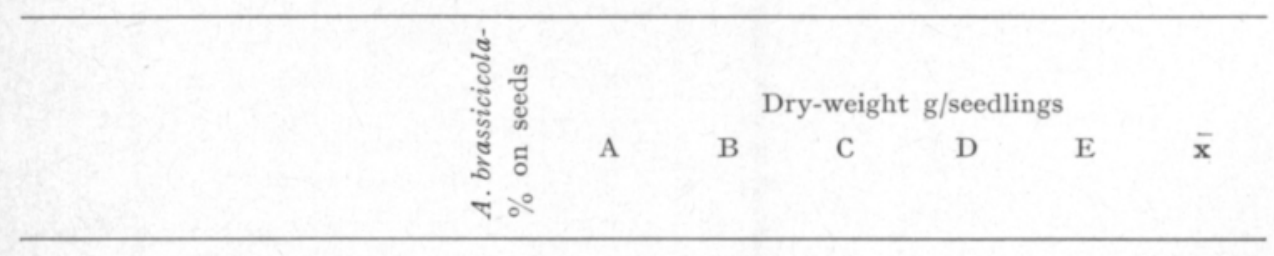

\begin{tabular}{llllllll} 
White cabbage 'Futura' & 81 & 0.29 & 0.35 & 0.38 & 0.24 & 0.25 & 0.30 \\
Cauliflower 'Erfurter 291' & 51 & 0.23 & 0.28 & 0.24 & 0.17 & 0.25 & 0.24 \\
Red cabbage 'Amager 304' & 78 & 0.26 & 0.25 & 0.24 & 0.23 & 0.26 & 0.25 \\
\hline$\overline{\mathbf{x}}$ & & 0.26 & 0.29 & 0.29 & 0.21 & 0.26 & 0.26
\end{tabular}

F-values: treatments: $5.87^{* * *}, \mathrm{LSD}_{\mathrm{t} 0.05}=0.036 \mathrm{~g}$ 


\section{Discussion}

All the most important seed-borne fungal diseases which are mentioned in the relevant literature (NoBle and RichaRdSON 1968), apart from Mycospharrella brassicicola and Peronospora parasitica (Pers.) Tul., were found in the seed material representing cruciferous cultivated plants used in Finland. In general, the seeds were either healthy or only slightly infected, apart from those of white cabbage, red cabbage, kale and Brussels sprouts.

Plenodomus lingam, which NeErgaARD (1972) has placed in category B (other important plant pathogens) in the classification of seed-borne diseases, is considered to be the most important seed-borne fungus of crucifers. This fungus occurred in the greatest amounts on red cabbage seeds, the highest fungus content being $14 \%$. The fungus was also frequently found on white cabbage and swede seed, usually, however, at fungus contents of below $1 \%$. The fungus contents obtained in this study were, on the average, in good agreement with those obtained elsewhere (Lloyd 1959, NeErgaArd 1959, Richardson 1970, Giessmann and Daebeler 1973).

P. lingam was first found in Finland in 1865 (KARSTEN 1884), but since then no mention has been made of it, not even by Linnasalmi (1952) in his study on damping-off. Dry rot has obviously not been of much importance to field crops in Finland, unlike the case in moist, maritime climates (GIEsSMAnN and DAEBeler 1973), but it has caused damage in Finland during storage following damp autumns (TAHVonen 1978). Infection may have been derived from infected seed material, since health inspection is not carried out during the inspection of garden plant seeds in Finland.

Alternaria $s p p$. are also some of the most common seed-borne fungi of crucifers in Finland and hence are frequently included among the economically most damaging ones. The most common pathogenic species was A. brassicicola, which infected white cabbage, red cabbage, kale and Brussels sprouts seeds more severely than those of the other Crucifers studied. In most cases, the fungus contents were significantly higher than, for instance, those presented in the numerous studies carried out by NeERGAARD $(1945,1950,1951,1956$ a, b). According to MAUDE (1977), A. brassicicola has greatly increased during the last 20 years, which is borne out by the results obtained in this study.

There were extremely significant differences between the $A$. brassicicola contents of different species of Brassica. NeERgaARd (1945) states that this is mainly due to the type of weather prevailing at the time when the seeds are harvested. The varying resistance of different species, which became apparent in the pathogenicity tests, also partly affects the differences in fungus content. The different fungal isolates have hardly any effect since the differences in the pathogenicity tests were very small (cf. NerrgaArd 1945, Changsri and WeBBER 1963). The differences in A. brassicicola content between the different cabbage varieties are also explained by the different times when the seeds were harvested and possibly also by the differences in resistance. Further evidence for this was provided by the varying mortality rate of the seedlings during germination on the Jacobsen germinator. 
A. brassicae has no importance as a seed-borne fungus of Crucifers in Finland owing to the low degree of seed infection. The fungus was relatively more common on rape than on ohter Crucifers. Epidemics may possibly break out in Finland under exceptionally warm and moist conditions (cf. Dомsсн 1957), because the fungus is commonly present on seeds. A. brassicae was not found in any of the radish seed lots, although it has been found to be a common seedborne fungus of this plant in other countries (Groves and SKolko $1944 \mathrm{~b}$, NeErgaArd 1945, 1950, 1951, 1956 b, 1956 a, ANderson 1970).

A. raphani was the most common pathogen found on radish seeds, but it presumably has no importance in Finland owing to the low degree of infection in commercial seeds.

Other seed-borne fungi of Crucifers, which are also common on the seeds of other plants (Malone and MUSket 1964, YlimäKi 1970, MäKelä 1972, SALONEN 1972) are of no importance as a result of their uncommonness, such as Rhizoctonia solani, or their saprophytic nature. The number and content of other fungi, especially Fusarium spp., were low compared with seed-borne fungi of other plants. The occurence of Alternaria temuis was, however, worthy of attention because it was more often found on other Crucifers than on cabbages.

The importance of fungi carried by seed material has to be estimated by determining how they affect seedling development, yield, yield quality and storage before decisions can be made about quarantine orders and tolerance limits. The importance of seed-borne diseases in seedling raising has been surveyed in this study.

Of the seed-borne fungi affecting Crucifers, only P. lingam and A. brassicicola had any important effect on seedling emergence and seedling production. The temperature and the growth substrate, however, have a very significant effect on the magnitude of any subsequent damage.

$P$. lingam caused damping-off on the sterile substrate in direct proportion to the degree of infection of the seeds, independant of temperature. Inoculation of the surface of the seeds with this fungus also resulted in a high incidence of damping-off on the peat substrate. Since natural infection of seeds by this fungus usually takes place deep down in the seed coat or even in the embryo (JACOBSEN and Williams 1971), naturally infected seeds cause almost the same degree of damage on peat substrate as on sterile substrate.

In addition to the infection percentage, environmental factors have a decisive effect on the damage caused by $A$. brassicicola. A low, "traditional" temperature of $10-15^{\circ} \mathrm{C}$, which permits production of seedlings after $5-6$ weeks, decreases to an ext1emely significantly degree damping-off caused by A. brassicicola in comparison to the faster production of seedlings which requires a temperature of about $20^{\circ} \mathrm{C}$. This observation is supported by the temperature required by the fungus to attain optimum growth (WEIMER 1924, NeERgaARD 1945, RAngel 1945). The low temperature earlier used in Finland in seedling production explains the relatively rare occurrence of $A$. brassicicola as a damping-off agent (Linnasalmi 1952). Temperature plays an important role in the fast production techniques used by growers today, if disinfected substrates instead of peat are used. 
The substrate most commonly used in Finland, light-coloured Sphagnum fuscum raw peat, had a very strong fungistatic effect on $A$. brassicicola and also to some extent on $P$. lingam. In the best case, the fungistatic effect was comparable to dressing the seeds. When the A. brassicicola content of the seeds was less than $60 \%$, damping-off was only slight on the peat substrate. At levels above this infection percentage, more damage started to occur. De TEMPE (1968) has shown that a high seed infection percentage is usually associated with a high pathogenic ability of the fungus. The fungus thus has a high ability to withstand unfavourable conditions such as dressing and other microorganisms.

The increase in the ratio of seedling mortality- $\%$ and $A$. brassicicola- $\%$ du: ing germination, as the A. brassicicola- $\%$ increased, is also explained by de Tempe's (1968) studies. The strong infectability of Alternaria fungi at high infection percentages is caused by the fact the fungus passes deep down into the seed coat or even as far as the embryo (Samra 1956). Support for the presence of this phenomenon was obtained in this study during surface sterilisation, thiram dressing and in the seedling production experiments, in which even $A$. tenuis had damaged the cotyledons.

The fungistatic properties of the peat substrate were not examined in more detail in this study. Preliminary studies on the extent and significance of this phenomenon have already been carried out (TAHVONEN and REINIKAINEN 1976).

In damping-off studies, attention is usually only paid to the number of dead and damaged seedlings. The slowing-down of seedling growth caused by fungi has not been measured. In these experiments, A. brassicicola significantly slowed-down growth without apparently damaging the seedlings. This phenomenon may be due to toxins produced by fungi, which has earlier been mentioned in the literature (BoEK 1952, ten Houten 1952.). The slowingdown of growth at the seedling stage may later affect the development of the plant.

The spread of seed-borne fungi from infected to healthy seeds is only slight or almost non-existant when fresh peat is used as the substrate. The seedling raising methods used at the present time in Finland, in which the seedlings are grown in $\mathbf{5} \mathrm{cm}$ diameter peat or paper pots or extruded containers, reduces the risk of damping-off in comparison to the earlier used broadcast sowing method. In the old method, under moist conditions especially, $P$. lingam could rapidly spread from slightly infected $(0.5 \%)$ seeds throughout the dense seedling stand (Allen and Sмith 1961).

Seed-borne fungi on rape, turnip rape, swede, turnip and radish seeds had no practical significance at the emergence or seedling stage owing to the low fungus contents.

In Finland, it is always worth dressing Crucifers, especially cabbage, with thiram owing to the lack of stringent seed examination. Sometimes, however, despite dressing damage caused by seed-borne diseases can occur because thiram dressing is not completely effective if the seeds are strongly infected (Jacobsen and Williams 1971, Maude 1977). 


\section{Summary}

The aim of this study was to determine which are the most common seedborne fungi of Cruciferous crop plants and what is their importance under different conditions during the seedling stage and in different growth substrates. The seed material was obtained from the State Seed Testing Station, the Institute of Horticulture at Piikkiö, the Institute of Horticulture of the University of Helsinki and from different seed merchants either bought or provided free of charge. The material consisted of 272 seed lots available on the market during the period 1968-1976. Their health was studied by germinating them by the blotter method on a Jacobsen germinator and partly by germinating them by the agar method using maize medium at $20^{\circ}$ and $5^{\circ} \mathrm{C}$. The pathogenicity tests were carried out by germinating the surface infected seeds under constant conditions on a Jacobsen germinator. The seedlings were grown in sand, steam-sterilised soil and fresh peat in plastic boxes and plant pots kept in either the laboratory, greenhouse or growth cabinet (Vötsch). The seed dressing trials were done using an $80 \%$ thiram preparation.

1. Alternaria brassicicola (Schw.) Wiltshire was the most common seedborne pathogen of the Cruciferous plants studied. White cabbage, red cabbage, kale and Brussels sprouts were the severest and most frequently infected (88$100 \%$ of the lots). The $A$. brassicicola content of the infected white cabbage lots was $29.5 \%$, of the red cabbage $30.6 \%$, of the Brussels sprouts $23.3 \%$ and of the kale $22.3 \%$. The highest fungus contents were $65-99 \%$. There were differences between the degree of infection of the different varieties of white cabbage. The seeds of kohl-rabi, rape, black radish, swede and turnip were either healthy or else there was one slightly infected lot only. The other plant species examined were slightly infected. There were differences between the resistance of different species against $A$. brassicicola.

2. Plenodomus lingam (Tode ex Fr.) Höhnel was found on white cabbage, cauliflower, red cabbage, swede and radish seeds. $10 \%$ of the cabbage seed lots were infected and $27 \%$ of the red cabbage ones. The fungus contents varied from $0.5-3 \%$, apart from two lots of red cabbage which had fungus contents of $6 \%$ and $14 \%$.

3. Alternaria brassicae (Berk.) Sacc. was found in $4 \%$ of the cabbage, one of the kale and $31 \%$ of the radish seed lots. The fungus contents varied from 0.5 to $6.5 \%$.

4. Alternaria raphani Groves \& Skolko was found in about $30 \%$ of the radish and black radish seed lots at fungus content of $0.5-8 \%$.

5. Other pathogenic or slightly pathogenic seed-borne fungi found in the seed lots were Pleospora herbarum (Pers.) Rabenh., Whetzelinia sclerotiorum (Lib) Korf \& Dumont, Botrytis cinerea Pers., Ulocladium concortiale (Thum.) Simmons, Fusarium spp. and Rhizoctonia solani Kühn.

6. In addition, the following fungi were isolated from the seeds of Cruciferous plants: Acremoniella atra (Corda) Sacc., Actinomucor spp., Atrhrinium phaespermum (Corda) M. B. Ellis, Aspergillus spp., Chaetomium spp., Cladosporium clasporioides (Fres.) Vries, Gonatobotrys simplex Corda, Helminthosporium sativum Pammel, King \& Bakke, Ostragoderma stata Peziza ostragoderma 
Korf, Phoma herbarum Westd., Mucor spp., Rhizopus nigrigans Ehrenberg, Sordaria sp., Stachybotrys atra Corda and Verticillium spp.

7. Alternaria brassicicola caused a significant amount of damping-off and seedling damage when present in large amounts on the seeds. A fungus content of about $20 \%$ caused $10 \%$ damage on the sterile sand substrate, a corresponding amount of damage occurring on the peat substrate only when the fungus content was over $70 \%$.

8. Alternaria brassicicola caused only a small amount of damping-off before emergence on the sterile substrate, and not at all on the peat substrate.

9. In addition to causing damping-off, Alternaria brassicicola also sloweddown the growth of the seedlings without causing any apparent damage.

10. Significantly less damping-off was caused by Alternaria brassicicola when the seedlings were grown at a low temperature of $8-15^{\circ} \mathrm{C}$ than at a higher temperature of $18-25^{\circ} \mathrm{C}$.

11. Plenodomus lingam was a strong damping-off fungus which killedoff as many seedlings as were infected by the fungus. The damage caused by this fungus was not as greatly affected by temperature and the choice of substrate as was $A$. brassicicola.

12. Sphagnum fuscum peat, which is commonly used in Finland as a substrate, significantly reduced the amount of damage caused by seed-borne fungi in comparison to disinfected substrates.

13. Alternaria brassicicola and Plenodomus lingam did not spread on the peat substrate from diseased to healthy seedlings when the sowing spacing was greater than $4 \mathrm{~cm}$.

14. Inoculation of the peat substrate before sowing with the most important seed-borne fungi did not cause damping-off but the growth of the seedlings was slowed down slightly.

15. Thiram dressing of vegetable plants, which is approved in Finland, gave good protection against Alternaria brassicicola.

\section{REFERENCES}

Ainsworth, G. C., Sparrow, F. K. \& Sussman, A. S. 1973 a. The Fungi. IV A. 621 p. New York and London.

- 1973 b. The Fungi. IV B. 504 p. New York and London.

Allen, J. D. \& Sмiтh, H. C. 1961. Dry-rot (Leptosphaeria maculans) of Brassicas: seed transmission and treatment. N. Z. J. Agr. Res. 4:676-685.

Andersen, H. 1960. 21. Årsberetning vedrørende frøpatologisk kontrol 1. juni $1968-31$. maj 1968. - Stat. Pl. tilsyn 18: 27-45.

Anon. 1966. International Rules for Seed Testing 1966. Proc. Intern. Seed. Test. Ass. 31: 1-152.

Atrinson, R. G. 1950. Studies on the parasitism and variation of Alternaria raphani. Can. J. Res. Sec. C 28: 288-317.

BARKER, K. F. 1947. Seed transmission of Rhizoctonia solani in relation to control of seedling damping-off. Phytopath. 37: 912-924.

ВоEK, K. 1952. Einige Untersuchung an samenübertragbaren Krankheitserregern der Kruzifern. Dipl.-Arbeit, Universität Hamburg. (Ref. Domsch, K. H. 1957). 
Boerema, G. H. \& Kesteren, H. A. van 1964. The nomenclatur of two fungi parastizing Brassica. Persoonia 3:17-28.

Bontea, V. 1953. Putregaiul negru san putrgaiul uscat al Verzei. Anal. Inst. Crec. Agron. Rom. N. S. 22: 379-427.

Changsri, W. \& Weber, G. F. 1963. Three Alternaria species pathogenic on certain cultivated crucifers. Phytopath. 53: 643-648.

ChUPp, C. 1935. Macrosporium and Colletotrichum rots of turnip roots. Phytopath. 25: 269274.

Cleyton, E. E. 1925. Second progress report on seed treatment for black leg (Phoma lingam) and black rot (Pseudomonas campestris) of cruciferous crops. Phytopath. 15: 49.

Domsch, K. H. 1957. Die Raps- und Kohlschotenschwerze. Z. Pfl. krankheiten und Pfl. schutz $64: 65-79$.

Ellis, M. B. 1971. Dematiaceous hyphomycetes. 608 p. Kew, Surrey.

Gabrielson, R. L., Mulanax, M. W., Matsuoka, K. Williams, P. H., Whiteaker, G. P. \& Maguire, J. D. 1977. Fungicidal eradication of seedborne Phoma lingam of crucifers. Pl. Dis. Rep. 61: 118-121.

Giessmann, H. J. \& Daebeler, F. 1973. Untersuchungen zur Biologie und Bekämpfung des Pilzes Phoma lingam (Tode ex Fr.) Desm. an Kpfkohl. Arh. Phytopath. und Pfl. schutz 9: 5-13.

Groves, J. W. \& Sкоцко, A. J. 1944 a. Notes on seed-borne fungi I. Stemphylium. Can. J. Res. Sec. C. 22: 190-199.

- 1944 b. Notes on seed-borne fungi II. Alternaria. Can. J. Res. Sec. C. 22: 217-234.

Henderson, M. P. 1918. The blackleg disease of cabbage caused by Phoma lingam (Tode) Desmaz. Phytopath. 8: 379-431.

Houten, J. G. ten 1952. Koolzaad. Jaarversl. Inst. Pl. ziektenk. Onderz.: 66-68. (Ref. Domsch, K. H.)

Huber, G. A. \& Gould. C. J. 1949. Cabbage seed treatment. Phytopath. 39: 869-875.

Jacobsen, B. J. \& Williams, P. H. 1971. Histology and control Brassica oleracea seed infection by Phoma lingam. Pl. Dis. Rep. 55: 934-938.

Kampen, J. van 1964. 9e Jaarversl. Proefstation Groenteteelt Vollegrond Nederl.1963. 141 p.

Karsten, P. A. 1884. Symb. Mycol. Fenn. 13: 23.

LrNdaU, G. 1907. Fungi imperfecti in Rabenhorst, L. Kryptogamen-Flora von Deutschland, Österreich und Schweiz. 1, 8, 983 p. Leipzing.

Lrnnasalmi, A. 1952. Damping-off on herbaceous vegetables and ornamental plants grown under glass in Finland. Ann. Bot. Soc. 'Vaanmo' 26: 1-120.

Lloyd, H. B. 1959. The transmission of Phoma lingam (Tode) Desm. in the seeds of swede, turnip, chou moellier, rape and kale. N. Z. J. Agr. Res. 2: 649-658.

Loof, B. 1959. Ekonomiskt viktiga sjukdomar på korsblomstriga oljeväxter och möjligheterna till deras bekämpning specielt genom resistentsförädling. Sver. Utsädesför. Tidskr. 69: $237-450$.

Louver, J. 1958. La maladie des taches noires du Colza, Alternaria brassicae (Berk.) Sacc. Acad. Agric. Fr. 44: 694-701.

Macnish, G. C. 1963. Black leg of cabbage and related plants. J. Agric. W. Austr. 4: 167-170.

Malone, J. P. \& Musketr, A. E. 1964. Seed borne fungi. Proc. Int. Seed Test. Ass. 29: 179384.

MaUde, R. B. 1977. Alternaria. Routine sprays to check seed crop disease now under test. Grower 88: 288-291.

-, Vizor, A. S. \& Shuring, C. G. 1969. The control of fungal seed-borne diseases by means of a thiram seed soak. Ann. Appl. Biol. 64: 245-257.

Mcdonald, W. C. 1959. Grey leaf spot of rape in Manitoba. Can. J. Pl. Sci. 39: 409-416.

Mclean, D. M. 1947. Alternaria blight and seed infectin a cause of low germination in certain radish seed crops. J. Agr. Res. 75: 71-79.

- 1949. Occurance of Sclerotinia stalk rot in cabbage seed plants in Skagit County, Washington, in 1948. Pl. Dis. Rep. 33:222-223.

- 1958. Role of dead flower parts in infection of certain crucifers by Sclerotinia slerotiorum (Lib.) D By. Pl. Dis. Rep. 42: 663-666. 
Morton, F. J. 1964. Species of Alternaria on Brassica hosts in New Zealand. N. Z. J. Bot. 2: $19-33$.

MäKELÄ, K. 1972. Seed borne fungi on cultivated grasses in Finland. Acta Agr. Fenn. 124, 2: $1-44$.

NegrgaArd, P. 1945. Danish species of Alternaria and Stemphylium. 560 p. Copenhagen.

- 1948. 11. - 12. åarsberetning fra J. E. Ohlsens Enkes Plantepatologiske laboratorium 1. August 1945- 31. Juli 1947. 19 p. Kobenhavn.

- 1950. 14. årsberetning fra J. E. Ohlsens Enkes planttepatologiske laboratorium 1. August 1948 - 31. Juli 1949. 23 p. København.

- 1951. 15. og sidsta årsberetning J. E. Ohlsens Enkes plantepatologiske laboratorium 1. August $1949-31$. Juli 1950. 33 p. København.

- 1956 a. 6. årsberetning vedrørende frøpatologisk kontrol 1. April 1953 - 31. Maj 1954. Statens plantetilsyn. 17 p. København.

- 1956 b. 7. årsberetning vedrørende frøpatologisk kontrol 1. Juni 1954-31. Maj 1955. Statens plantetilsyn. 17 p. København.

- 1958 a. Infection of Danish seeds by Rhizoctonia solani Kühn. Pl. Dis. Rep. 42: 12761278.

- 1958 b. Mycelial seed infection of certain crucifers by Sclerotinia sclerotiorum (Lib.) D. By. Pl. Dis. Rep. 42: $1105-1106$.

- 1969. Plenodomus lingam, black-leg of crucifers. Occurence in Danish seed lots for export, and control by germisan - hot-water treatment. Friesia 9: 167-179.

- 1972. Types of seed-borne plant quarantine objects classification into the categories outlined in lists A, B and C. Proc. Int. Seed Test. Ass. 37: 125-138.

NiELSEN, O. 1932. Undersøgelser over sblack leg» paa kaal og tørforraadnelse paa kaalroer. Tidskr. Pl. avl. 38: 131-134.

- 1933. Forsøg med bekämpelse af skulpesvamp. Tidskr. Pl. avl: 39:437-452.

Noble, M. \& Richardson, M. J. 1968. An annoted list of seedeborne diseases. Proc. Intern Seed Test. Ass. 33: 1-191.

Pound, G. S., Sheo, P-C., Calvert, O. H. \& RaAbe, R. D. 1951. Extent of transmission of certain cabbage pathogens by seed grown in western Washington. Phytopath. 41: $820-828$.

Rangel, J. F, 1945. Two Alternaria diseases of cruciferous plants. Phytopath. 35: 1002-1007.

Richardson, M. J. 1970. Investigations on seed-borne pathogens of Brassica spp. Proc. Int. Seed Test. Ass. 35: 207-223.

SALONEN, A. 1972. On the seed-borne fungi of red clover in Finland. Ann. Agric. Fenn. 11: $347-353$.

SamrA, A. S. 1956. Relative volue and mode of action of some fungicides used as seed disinfectants and protectants. Meded.| Landb. Hogesch., Wageningen 56, 1: 1-55.

Schimmer, F. C. 1953. Alternaria brassicicola on summer cauliflower seed. Pl. Path. 2: 16-17.

SCHNEIDER, R. 1960. Über einen bemerkenswerten Befall an Kohlrabi verurascht durch Phoma lingam (Tode) Desm. Nachr.bl. Deut. Pfl. schutzd. 13:26-28.

Smith, H. C. \& Sutron, B. C. 1964. Leptosphaeria maculans the ascogenous stata of Phoma lingam. Trans. Prit. Mycol. Soc. 47: 159-165.

SNYBer, W. C. \& BAKER, K. F. 1950. Occurance of Phoma lingam in California as a subterranean pathogen of certain crucifers. Pl. Dis. Rep. 34:21-22.

TAHvonen, R. 1978. Vihannesten varastointitaudit viljelyn riskitekijänä. Puutarha-alan hankinta opas, 15. rationalisointipäivät $17,-20.8$. 78:60-61.

- \& Reinikainen, O. 1976. Turvealustan sienitautien leviämistä estävä vaikutus. Puutarha 79: $348-349$.

Tempe, J. de 1963. The blotter method for seed health testing. Proc. Int. Seed Test. Ass. 28: 133-151.

- 1968. The quantitative evaluation of seed-borne pathogenic infection. Proc. Int. Seed Test. Ass. 33: 573-581.

WALKER, J. C. 1923. The hot water treatment of cabbage. Phytopath. 8:251-253.

- 1952. Diseases of vegetable crops. 529 p. New York, Toronto, London.

Wermer, J. L. 1924. Alternaria leaf spot and brown rot of cauliflower. J. Agric. Res. 29: 421-441. 
Wiltshire, S. P. 1947. Species of Alternaria on Brassicae. Mycol. Pap. 20:1-15.

Williams, P. H. 1967. Occurance of Phoma lingam on cabbage seed from Australia after treatment with hot water. Pl. Dis. Rep. 51: 566-569.

YLIMÄKI, A. 1970. The microflora of cereal seeds in Finland. Ann. Agric. Fenn. 9: 293-295.

YLLö, L. 1972. Valtion siementarkastuslaitos 1969/70. Maatilahall. tied. 371:1-28.

\title{
SELOSTUS
}

\section{Ristikukkaisten viljelykasvien siemenlevinteiset sienet Suomessa ja niiden merkitys taimikasvatuksessa}

\author{
Risto TAHVONEN \\ Helsingin yliopiston kasvipatologian laitos
}

Tämän tutkimuksen tarkoituksena oli selvittää yleisimpien ristikukkaisten viljelykasvien siemenlevintäiset sienet Suomessa ja niiden merkitys eri olosuhteissa taimivaiheessa ja kasvualustassa. Siemenaineisto saatiin Valtion siementarkastuslaitokselta, Puutarhantutkimuslaitokselta, Helsingin yliopiston puutarhatieteen laitokselta ja eri siemenliikkeistä lahjoituksina ja osin ostaen. Aineisto käsitti 272 vuosina 1968-1976 kaupassa ollutta siemenerää, joiden terveys tutkittiin blotter-menetelmällä idättämällä siemeniä Jacobsenin idätysaltaalla ja osin agar- menetelmällä idättämällä siemeniä maissialustalla $20^{\circ} \mathrm{C}: s s a$ ja $5^{\circ} \mathrm{C}: s s a$. Patogeenisuuskokeet suoritettiin idättämällä pintasaastutettuja siemeniä vakio-olosuhteissa Jacobsen idätysaltaalla. Taimikasvatukset tehtiin hiekka-, höyrytetyllä multa- ja uudella turvealustalla muovisissa laatikoissa ja ruukuissa laboratoriohuoneissa, kasvihuoneessa ja kasvatuskaapeissa (Vötsch). Peittauskokeet tehtiin $80 \%$ :lla tiraami-valmisteella (Pomarsol Forte).

1. Alternaria brassicisola (Schw.) Wiltshire oli ristikukkaisten kasvin yleisin siemenlevintäinen taudinaiheuttaja. Kerä-, puna-, rehu- ja ruusukaali olivat voimakkaimmin ja useimmin (88-100\% eristä) saastunut. Infektoituneiden erien A. brassicicola-pitoisuus oli keräkaalilla keskimäärin $29.5 \%$, punakaalilla $30.6 \%$, ruusukaalilla $23.3 \%$ ja rehukaalilla $22.3 \%$. Korkeimmat sienipitoisuudet olivat $65-99 \%$. Eri keräkaalilajikkeiden infektoituneisuudessa oli eroja. Kyssäkaalilla, rapsilla, retikalla, lantulla ja nauriilla olivat siemenet terveitä tai vain yksi lievästi saastunut erä. Muut kasvilajit olivat lievästi saastuneita. Eri lajien A. brassisicola-kestävyyksissä oli eroja.

2. Plenodomus lingam (Tode ex Fr.) Höhnel -sientä oli kerä-, kukka- ja punakaalin sekä lantun ja retiisin siemenillä. Keräkaalilla oli $10 \%$ ja punakaalilla $27 \%$ siemeneristä infektoitunut. Sienipitoisuudet olivat $0.5-3 \%$ kahta punakaalierää lukuunottamatta, joissa oli $6 \%$ ja $14 \%$ tätä sientä.

3. Alternaria brassicae (Berk.) Sacc. oli $4 \%: s s a$ kerä- ja yhden lehtikaalin sekä $31 \%: s s a$ rapsin siemeneristä $0.5-6.5 \%: n$ pitoisuuksina.

4. Alternaria raphani Groves \& Skolko oli retiisin ja retikan siemenillä n. $30 \%: s s a$ eristä $0.5-8 \%$ :n pitoisuuksina.

5. Muita patogeenisia tai lievästi patogeenisia siemenlevintäisiä sieniä olivat Pleospora herbarum (Pers.) Rabenh., Whetzelinia sclerotiorum (Lib) Korf \& Dumont, Botrytis cinerea Pers., Ulocladium conortiale (Thum.) Simmons, Fusarium spp. ja Rhizoctonia solani Kühn.

6. Ristikukkaisten kasvien siemeniltä tavattiin lisäksi seuraavat saprofyyttiset tai muille kasveille patogeeniset sienet: Acremoniella atra (Corda) Sacc., Actinomucor spp., Artrinium phaespermum (Corda) M. B. Ellis, Aspergillus spp., Chaetomium spp., Cladosporium cladosporioides (Fres.) Vries, Gonatobotrys simplex Corda, Helminthosporium sativum Pammel, King \& Bakke, Ostragoderma stata Peziza ostragoderma Korf, Phoma herbarum Westd., Mucor spp., Rhizopus nigrigans Ehrenberg, Sordaria sp., Stachybotrys atra Corda ja Verticillium spp.

7. Alternaria brassicicola aiheutti merkittävästi taimipoltetta ja taimien viottumista esiintyessään runsaana siemenellä. Steriilillä hiekka-alustalla n. $20 \%$ :n sienipitoisuus siemenessä aiheutti $10 \%$ :n tuhon, joka turvealustalla savutettiin vasta yli $70 \%: n$ sienipitoisuudella. 
8. Alternaria brassicicola aiheutti steriilissä kasvualustassa lievää maanalaista toimipoltetta, jota ei esiintynyt turvealustassa.

9. Alternaria brassicicola aiheutti taimipoltteen lisäksi taimien kasvun hidastumista ilman näkyviä viotuksia.

10. Alternaria brassicicola aiheutti merkitsevästi vähemmän taimipoltetta alhaisessa, 8$15^{\circ} \mathrm{C}: \mathrm{n}$ taimikasvatuslämpötilassa kuin korkeassa, $18-25^{\circ} \mathrm{C}: \mathrm{n}$ lämpötilassa.

11. Plenodomus lingam oli voimakas taimipoltesieni, joka tappoi taimia yhtä paljon kuin siemenessä oli sientä ja jonka aiheuttamiin tuhoihin eivät lämpötila ja kasvualusta vaikuttaneet niin voimakkaasti kuin $A$. brassicicola -sieneen.

Suomessa kasvualustana käytettävä Sphagnum fuscum -rahkaturve vähensi merkitsevästi siemenlevintäisten sienien aiheuttamia tuhoja verrattuna desinfioituihin alustoihin.

12. Alternaria brassicicola ja Plenodomus lingam eivät levinneet turvealustassa sairaista siemenistä terveisiin taimiin yli $4 \mathrm{~cm}: n$ etäisyydelle.

13. Ennen kylvöä turvealustaan inokuloidut tärkeimmät siemenlevintäiset sienet eivät aiheuttaneet taimipoltetta, mutta hudastivat hieman taimien kasvua.

14. Suomessa hyväksytty vihanneskasvien tiraami-peittaus tehosi hyvin Alternaria brassicicola-sieneen. 